\title{
SCOTLAND'S BASTARD VERDICT: INTERMEDIACY AND THE UNIQUE THREE-VERDICT SYSTEM
}

\author{
Joseph M. Barbato*
}

Veredictum quasi dictum veritatis; ut judicium quasi juris dictum. ${ }^{\dagger}$

\section{INTRODUCTION}

In 1707, the separate kingdoms of Scotland and England reached an accord whereby each was dissolved and the two united into the new Kingdom of Great Britain. ${ }^{1}$ After three hundred years, the Scottish Parliament has devolved from the larger Parliament of the United Kingdom. ${ }^{2}$ Scotland's desire to retain sovereignty is apparent in retrospect. For instance, one of the important Acts of Union between both countries' parliaments in the early 1700 s was to preserve the separate identity of the Scottish legal system and institutions. $^{3}$

This note will consider one small but emblematic part of Scotland's legal system, the verdict of "not proven." Part Two begins with the concept of Scotland's national identity, and follows the chronological development of the country's three-verdict system. With this foundation, two comprehensive legal reviews involving the not proven verdict, both of which resulted in its retention, are discussed. Part Three examines post-millennial developments in the not proven debate, and also compares how this uniquely Scottish verdict has made an imprint on the American legal system. Finally, Part Four takes into account renewed controversy in Scotland over the verdict, recognizing that the potential costs of doing away with "not proven" currently outweigh possible benefits.

* J.D. candidate, May 2005. M.F.A., Purdue University, 2002. B.A., Purdue University, 1998. The author would like to thank his wife, Hannah, for her love, support, and forbearance throughout the law school experience. He also wishes to thank Dr. Christine Slater for taking time to locate several sources in Scottish libraries, and the Executive Board of Volume 14 for seeing enough potential to select this note for publication.

$\dagger$ "A verdict is, as it were, the saying of the truth, in the same manner that a judgment is the saying of the law (or right)." BLACK's LAw DiCTIONARY 1699 (7th ed. 1999).

1. Michael C. Meston, Scots Law Today, in THE Scottish Legal Tradition 1, 2 (new enlarged ed., Scott C. Styles ed., 1991).

2. See Scotland Act, 1998 , c. 46 (Scot.), http://www.hmso.gov.uk/acts/acts1998/1998 0046.htm (last visited Feb. 19, 2005).

3. Meston, supra note 1 . While this was true, Meston points out that "[t]here was little protection for the substance of the existing Scots law." Id. Perhaps this gave increased importance to maintaining the institutions applying the law, such as the Court of Session (civil court) and Court of Justiciary (criminal court), which "were to remain in all time coming within Scotland." Id. 


\section{SOMEWHERE IN THE MIDDLE}

Today, the status of Scotland within the international community is not easily categorized. Standing alone, Scotland is neither solely whole nor part, but somewhere in the middle. Perhaps it is both. For example, a Scotsman would never agree that he was also an Englishman, but would concede that both are nonetheless Britons. ${ }^{4}$ This same attitude is found in the legal profession, where the "fierce independence of the Scots lawyer" is directly connected to the fear "that a merger with English law would, through English ignorance, become a mere abolition of Scottish law and institutions."

Lord Cooper ${ }^{6}$ suggests that Scottish law and society are inextricably linked: "[O]f all the items which add up to make the sum total of [Scotland's] heritage none is more distinctive than Scotland's contribution to law."7 By preserving the identity of its legal institutions, Scotland has also preserved its societal heritage, because "Scots Law is in a special sense the mirror of Scotland's history and traditions and a typical product of the national character, and it is just as truly a part of [the] national inheritance as [the] language or literature or religion."

This attribute of being in the middle-intermediacy, for lack of a better term-is also an intrinsic characteristic of the Scottish legal system, which holds an "ambivalent position" between the common law (of English or AngloAmerican heritage) and the civilian tradition (also called Continental or Romano-Germanic). ${ }^{9}$ As Lord Cooper says, "Scotland stands apart, content with a system of her own devising, which ... now occupies a position somewhere midway between the two great opposing schools."10 Furthermore, "Scots law is unique in the extent to which it has drawn on and been influenced by both these great traditions throughout most of its long history." 11 This

4. Id. at 1. Meston also points out the surprise of foreigners at the degree of separation of the countries' parts, apparent in the confusion in naming the country as England, Great Britain, or the United Kingdom of Great Britain and Northern Ireland. Id.

5. Id. at 3.

6. Former President of the Court of Session, and author of the original text entitled The Scottish Legal Tradition. Scott C. Styles, Introduction to The ScotTish Legal Tradition xi (new enlarged ed., Scott C. Styles ed., 1991).

7. Lord Thomas Mackay Cooper, The Scottish Legal Tradition, in THE ScOTTISH LEGAL TRADITION 65 (new enlarged ed., Scott C. Styles ed., 1991).

8. Id.

9. W. David H. Sellar, A Historical Perspective, in ThE SCOTTISH LEgal TRADITION 29 (new enlarged ed., Scott C. Styles ed., 1991); see also Alexander J. Black, Separated by a Common Law: American and Scottish Legal Education, 4 IND. INT'L \& COMP. L. REV. 15, 17-20 (1993) (discussing the historical background of Scottish legal philosophy, and stating that "Scotland [has] a mixed legal system, part civil law, part common law, as is the nominal classification in Québec, Louisiana, or South Africa").

10. Cooper, supra note 7 , at 66 .

11. Sellar, supra note 9, at 29-30. Sellar also says that "Scots law has always been more of a hybrid than Cooper was prepared to admit, and the influence of the Civil or Roman law on 
history is "one of great antiquity and continuity," itself a distinguishing feature of Scottish law, "which can be traced from the earliest times of which there is any record right down to the present day."12

In this context, Scottish intermediacy is echoed in its three-verdict criminal system, in which a Scottish jury ${ }^{13}$ returns a verdict by majority, and "may, unless they have been specially directed in law that one or another is not open to them, be any one of 'guilty,' 'not guilty,' or 'not proven." 14 While the first two are self-explanatory, the third, being found somewhere in the middle, requires clarification. ${ }^{15}$ Unfortunately, there is no common law or statutory definition of "not proven." 16 Even so, one of its defining features is that it counts as a vote for acquittal, resulting in the verdicts of not guilty and not proven having exactly the same legal effect. ${ }^{17} \mathrm{~A}$ verdict of not proven, however, carries more than mere legal effect: "It is generally suggested that a verdict of not guilty means that the judge or jury thinks that the accused definitely did not commit the crime..., whereas a verdict of not proven means merely that the judge or jury has reasonable doubt as to the accused's guilt." 18 The implication that the accused's guilt has not been conclusively demonstrated ${ }^{19}$ has resulted in the labeling of the not proven verdict as a “"second class' acquittal.",20

Perhaps because of these implications, the not proven verdict "continues to attract bemused attention from outside Scotland." 21 At the same time, it is a source of frustration within Scottish jurisprudence, especially for those people

Scots law has never operated in a context unaffected by the countervailing influence of the English Common law." Id. at 30.

12. Id. at 29. Sellar puts forth that "[i]n England and Scotland, . . a apart from the brief period of Commonwealth and Protectorate in the mid- $17^{\text {th }}$ century, there has been no revolution, nor has a written code of law been adopted to mark a new departure." Id.

13. "[I]t is important to note that the verdict of not proven is available also to sheriffs hearing summary cases and to justices in the district court," both without juries, who return the verdict in around one-fifth of their acquittals, as compared to about one-third by juries. Peter Duff, The Not Proven Verdict: Jury Mythology and "Moral Panics", 41 JURID. Rev. 1, 7 (1996).

14. David M. WALKer, The ScotTiSh Legal SySTEM 550 (8th ed. rev., W. Green/Sweet \& Maxwell, Edinburgh 2001). "Importance attaches to corroboration; by Scots law every essential fact must be corroborated, i.e., the evidence must be supported by independent evidence from another witness or from facts and circumstances justifying an inference to the same effect." Id. at 549 . The jury may give its verdict unanimously, or by a majority. Id. at 529.

15. Duff, supra note 13, at 6; see also W. M. GloAg \& R. C. Henderson, InTROduction TO THE LAW OF SCOTLAND 764 (7th ed., Alastair M. Johnson \& J. A. D. Hope eds.,W. Green \& Son Ltd., Edinburgh 1969).

16. Peter Duff, The Scottish Criminal Jury: A Very Peculiar Institution, 62 LAw \& CONTEMP. PROBS. 173, 193 (1999).

17. Duff, supra note 13 , at 6 .

18. Id.

19. Duff, supra note 16.

20. Duff, supra note 13, at 6 (quoting the 1975 Thomson Committee report on criminal procedure in Scotland).

21. Meston, supra note 1 , at 27. 
annoyed with the "ambivalent position" of an intermediate verdict, who prefer a bright line rule or black-letter law. ${ }^{22}$ One such person was Sir Walter Scott. ${ }^{23}$ In 1827, after attending the trial of a woman accused of poisoning a servant girl, he wrote in his diary: "She is clearly guilty, but as one or two witnesses said the poor wench hinted an intention to poison herself, the jury gave that bastard verdict, not proven." ${ }^{24}$ He went on, "I hate that Caledonian medium quid. One who is not proved guilty is innocent in the eyes of the law."25

Scott was neither the first nor last to speak out on the verdict, as shown by Willock's preface to a discussion of the topic: "The history of the three modern Scottish verdicts holds a particular interest in view of the frequent controversies that have arisen as to the desirability of the apparently anomalous verdict of 'not proven'." ${ }^{26}$ Lord Cooper shares this general sentiment, suggesting, "If you would know what a thing is, you must know how it came to be what it is: and if we are to acquire a just perspective for a brief survey of the modern law, we must consider first the pedigree of its leading doctrines."27

\section{A. Chronological History of the Caledonian Medium Quid}

For approximately 300 years, the not proven verdict has been a part of the Scottish criminal justice system, even though it is the "product of historical accident."28 More specifically, the verdict's origin has been to some extent "traced to the recognition of the inability of an unskilled jury to interpret the significance of particular facts." 29 As a result, "if it is to be regarded as an institution to be valued, it can scarcely be claimed as a manifestation of the

22. Sellar, supra note 9.

23. Neil Gow, The Case for Not Proven, 143 New L. J. 753 (1993). Scott was not only a novelist, but also an advocate and sheriff in Selkirk. Id.

24. Id. See also IAN Douglas WILOCK, The ORIGINS AND DeVELOPMENT OF THE JURY IN SCOTLAND 217 n.1 (The Stair Society, Edinburgh 1966). Scott also told her advocate: "All I can say is, that if that woman was my wife, I should take good care to be my own cook." Allan Massie, Arguing the Case for Our 'Bastard Verdict', SCOTSMAN, Nov. 22, 2004, at 17.

25. WwLCK, supra note 24, at 217 . Willock records the last line as "not proved" while Gow quotes it as "not proven." Gow, supra note 23. In a 1995 debate on the verdict, after Sir Walter Scott's famous line was quoted, one Member of Parliament stated:

[I]t is worth pointing out ... that one of the reasons that Sir Walter Scott was driven to write the Waverley novels was the fact that, up to then, he had had a rather unsuccessful career at the Scottish Bar. While he may be regarded as an authority on the $19^{\text {th }}$-century novel, he is not generally regarded as someone upon whom great reliance can be placed in important matters of Scots law.

221 Parl. DeB., H.C. (Hansard) (June 7, 1995) [hereinafter Hansard].

26. WILOCK, supra note 24 , at 217.

27. Cooper, supra note 7 , at 67.

28. Duff, supra note 13, at 6 . "The not proven verdict does not appear to be, or to have been, used in any other legal system." SCOTTISH OFFICE, JURIES AND VERDICTS: IMPROVING THE DELIVERY OF JUSTICE IN SCOTLAND 26 (HMSO, Edinburgh Press 1994) [hereinafter JURIES AND VERDICTS].

29. J. Irvine Smith, Criminal Procedure, in INTRODUCTION TO SCOTTISH LEGAL HISTORY 426, 442. (Robert Cunningham \& Sons, Ltd., Alva, Scotland 1958). 
genius of Scottish criminal jurisprudence."

\section{Sixteenth Century and Earlier}

The early juridical practice was to frame indictments in general terms, leaving the determination of guilt or innocence to the jury. ${ }^{31}$ Rudimentary records reveal that juries employed a wide variety of terminology to convey its verdict, following no set form. ${ }^{32}$ For instance, innocence was expressed by "made qwyt" (made quit) or "deliuerit innocent" (delivered innocent), and sometimes by "clene and sakles" (clean and sakeless). ${ }^{33}$ Guilt was rarely proclaimed by the simple use of "guilty," and more commonly by "convictus" or "convicit" and the phrases "in wrang" (in wrong) or "had done wrangis."34 The Justice Court at this time used similar terms to denote culpability and acquittal, with the addition of "fylit" (fouled) for guilty and "clangit" (cleaned) for innocent. ${ }^{35}$ Furthermore, isolated examples of "Giltye" and "nocht giltie" are found used in Edinburgh in the latter part of the sixteenth century. ${ }^{36}$

\section{Seventeenth Century}

A practice was adopted during the reign of Charles II that postponed the use of guilty and not guilty until the eighteenth century. ${ }^{37}$ Instead, the custom of producing indictments, including a long list of charges, emerged. ${ }^{38}$ Following from this, special verdicts for each charge, "proven" or "not proven," were introduced. 39 "The practice which thus arose of the jury finding certain facts proved was encouraged when juries between 1660 and 1688 refused to convict on prosecutions brought under unpopular and repressive Statutes. ${ }^{, 40}$

The response to this refusal to convict was the introduction of a doctrine stating that "in no case ... the jury had a right to exercise their judgment upon any point except the evidence relating to the different facts charged ...."41 In addition, "in every case they were to decide merely upon the fact; and it was the province of the judges to determine the import of their verdict, in the scale of guilt." Thus, the jury "merely found each of the charges proven or not

30. WILLCK, supra note 24, at 217.

31. Smith, supra note 29.

32. WILLOCK, supra note 24, at 217.

33. Id.

34. Id. 1998).

35. Id. See also 5 David M. WALKer, A Legal History OF Scotland 560 (T \& T Clark

36. WILLOCK, supra note 24 , at 217-18.

37. Id.

38. Id.

39. Id. at 218; see also WALKER, supra note 35.

40. Smith, supra note 29.

41. Id.

42. Id. 
proven," while the "actual inference of guilt . . was left to be drawn by the judge." 43

\section{Eighteenth Century}

In the first two decades of the eighteenth century, the verdicts of guilty and not guilty fell "completely into abeyance." 44 Instead, the practice of returning special verdicts finding certain facts proven and leaving the interpretation for the judges continued until the 1726 trial of Samuel Hale. ${ }^{45}$ Though only a step, it prepared the Scottish criminal legal system for the leap it was to make two years later. At the 1728 trial of Carnegie of Finhaven, "the jury's right to return such a verdict was emphatically reestablished," which acted to "halt ... a process of attrition which might have led to the total extinction of the criminal jury.",46

But the verdict of not proven did not "fall into the limbo of legal antiquities." 47 Juries retained the use of the special verdict, putting it into practice at the trial of Captain Porteous in 1736, finding each stage in the commission of the charged offense proven. ${ }^{48}$ In his lectures on the subject, David Hume ${ }^{49}$ explained the "new shade of meaning" acquired by the verdict:

43. WILLOCK, supra note 24 , at 219 . This change is attributed to the 1662 case of Marion Lawson, who was accused of murdering her newborn child. Id. The jury became confused as to the presumptions arising from facts presented, and was unwilling to convict on the evidence. Id. Perhaps this was because the jury received no direction from the bench. Smith, supra note 29.

44. WILLOCK, supra note 24 , at 220.

45. Smith, supra note 29 . Hale was accused of homicide. WILOCK, supra note 24 , at 220. The jury was satisfied with his defense, and without question from the bench brought a general verdict of not guilty. Id.

46. WILLOCK, supra note 24 , at 220-21. The accused was charged with the murder of the Earl of Strathmore, to which a defense of drunkenness was asserted. Id. While the evidence left no doubt of a fatal wounding during a quarrel, the accused claimed he had lacked the intent to cause death. Id. Carnegie's advocate requested a verdict of not guilty, assuring the jury that it remained a competent verdict, after which they found as he proposed. Id. In the crucial moment, it is recorded that Carnegie's zealous advocate

[I]nsisted[] that this was the critical moment which was either to rivet the prerogative of the crown over the privileges of the jury, or to emancipate them from the subordination and insignificance into which they had been degraded by a government[.] And that the liberties of their country, the blood of the innocent, and their future peace of mind, depended upon the degree of justice and resolution which they should display in the verdict they were about to pronounce.

S. A. Bennett, Not Proven: The Verdict, 12 SCOT. L. TIMEs 97, 97-98 (2002).

47. WILOCK, supra note 24 , at 221.

48. Id.

49. Most famous for his philosophical writings, Hume also studied and practiced law in Edinburgh. DAVID M. WALKER, ThE SCOTTISH JuRISTS 316-17 (W. Green \& Son, Ltd. 1985). He was recently voted as the "Scot who had made the greatest impact on Scotland in the last 1,000 years." Famous Scots - David Hume, at http://www.rampantscotland.com/famous/ blfamhume.htm (n.d.) (last visited Feb. 23, 2003). 
"Not uncommonly, the phrase not proven has been employed to mark a deficiency only of lawful evidence to convict . . . and that of not guilty, to convey the jury's opinion of his innocence of the charge."

\section{Nineteenth Century}

By the 1830 s, special verdicts were largely obsolete. ${ }^{51}$ However, the not proven verdict continued to be "retained for those cases in which there was insufficient lawful evidence to convict, but suspicion attached to the prisoner." 52 Furthermore, a consequence developed whereby "the verdict of not proven carrie[d] with it a certain stigma, as if the jury wished to record their disapproval of the accused and his behaviour." 53 Even so, "[w]hether the verdict of the Jury be in this form ... . or not guilty, . . the benefit is the same to the prisoner. He is for ever freed from any farther proceedings in regard to the matter laid before the Jury." 54

The cases from this period are full of intrigue because of the not proven verdict's new implications, as well as a major ramification of its use: avoidance of a death sentence, which was restricted to murder, piracy, and treason by the end of the century. "[J]uries frequently took refuge" in the not proven verdict to "avoid imposition of a capital sentence ...." The 1857 trial of Madeleine Smith was one example of a jury's use of the "hybrid verdict" for this purpose. ${ }^{57}$ There, no direction was given to the jury concerning the possible verdicts or their consequences, which seems to have been regarded by that time as common knowledge. ${ }^{58}$

Two other cases, both brought on charges of murder, also display the verdict in action. The 1843 trial of Christian Gilmour, involved the death of her husband after he consumed quantities of arsenic. ${ }^{59}$ Christian's father disallowed her betrothal to a poor young farmer, and instead arranged her

50. WILLOCK, supra note 24, at 221 (quoting Hume).

51. 6 DAVID M. WALKER, A LEGAL HISTORY OF SCOTLAND 456 (Butterworths/LexisNexis 2001).

52. Smith, supra note 29.

53. WILLOCK, supra note 24 , at 221-22.

54. WALKER, supra note 51. This quote is from Sir Archibald Alison, a contemporary of Hume, whose "work has taken a place and achieved an esteem second only to Hume as an authority on the criminal law, and in every criminal case raising a significant point of principle or common law it is examined." WALKER, supra note 49 , at 358.

55. S. Scott Robinson, Nineteenth Century Criminal Justice, 36 J. L. Soc'Y. Scot. 151 (1991). Furthermore, "[u]ntil 1834 there were, in Scotland, still some fifty crimes (as opposed to 300 in England) which could be visited with the capital sentence . . . . [It] was finally abolished by the Murder (Abolition of Death Penalty) Act 1965, except for mutiny in time of war, piracy and treason." Id.

56. Id.

57. WALKER, supra note 51.

58. Id. at 456-57.

59. S. Scott Robinson, Nineteenth Century Criminal Justice - The Trial of Christian Gilmour, 37 J. L. SOC'Y. SCOT. 16 (1992). 
marriage to a more established farmer, John Gilmour. ${ }^{60}$ Eight weeks later her husband was dead, and evidence showed Christian had purchased, on two different occasions, the poison used to kill him. ${ }^{61}$ The twenty-four-year-old woman claimed the poison was intended for herself and that she had no idea how her husband had ingested the substance. ${ }^{62}$ An hour after retiring, the jury returned a verdict of not proven on the charge of murder. ${ }^{63}$ It has been suggested that "the all-male jury, impressed by the mild and gentle appearance of the prisoner, and the awful consequences to her if they were to return a verdict of guilty of murder, had been much relieved to seize upon the old Scots verdict of not proven." $" 64$

The second case, heard by the High Court of Stirling in 1845, is that of Isabella Rae. ${ }^{65}$ Rendered suicidal by a hard life of poverty, Isabella threw herself into a canal while clutching her two-year-old son to her chest. ${ }^{66}$ Although she was pulled to safety, her son was drowned. ${ }^{67}$ She was charged with murder, or in the alternative, the lesser offense of culpable homicide. ${ }^{68}$ Her advocate mounted a "perilous but courageous line of defence," by suggesting there was no room for the lesser indictment: she was either guilty of murder, or not in a state of mind to be responsible for her actions. ${ }^{69} \mathrm{He}$ called for the verdict of not proven on both charges. ${ }^{70}$ It took the jury only two hours to agree. ${ }^{71}$ As with the Gilmour trial, perhaps the jury sympathized with this unfortunate woman, and having learned of the "conditions of abject poverty in which she was endeavouring to provide for three children, would have seized upon any explanation ... which would save her from the death sentence...., with all its appalling consequences for her and for the two surviving children." 72

60. Id.

61. Id.

62. Id. This claim seems to be a recurring theme, as it was the impetus (although in a different case, occurring twenty-six years earlier) for Sir Walter Scott's historical epithet. See supra notes 23-24 and accompanying text.

63. Robinson, supra note 59.

64. Id. See also WILLCK, supra note 24, at $221 \mathrm{n} .12$ (commenting on the "remarkable number of instances in which women charged with murder by poison were given this verdict" and suggesting that "juries were too easily swayed by improper sympathies").

65. S. Scott Robinson, Nineteenth Century Criminal Justice - A Perilous Defence - The Trial of Isabella Rae, 36 J. L. SoC'Y. SCOT. 309 (1991).

66. Id.

67. Id.

68. Id.

69. Id.

70. Id.

71. Id.

72. Id. 


\section{B. Modern Misconception and Misdirection}

While it may be easy to ascribe motive to the decisions of nineteenthcentury juries, it should be remembered that there is no duty upon the modern jury to explain its verdict. ${ }^{73}$ There are times, however, when a "peep through the veil" is obtained. ${ }^{74}$ One such instance happened when the foreman of a Scottish jury announced the verdict of "guilty by a majority," and the defense counsel was allowed to inquire as to what the majority had been. ${ }^{75}$ "[W]e were six for guilty; five for not guilty; and four for not proven," came the response, clearly totaling a majority for acquittal rather than guilt. ${ }^{76}$ The verdict of not guilty was entered as a result. ${ }^{77}$

This type of confusion was cause for concern on the part of judges, especially at a time when they were attempting to issue instructions explaining the not proven verdict to juries. ${ }^{78}$ For example, in a case concerning culpable homicide, Lord Cameron instructed the jury:

There are three possible verdicts which you can return upon this indictment. You can return a verdict of guilty of culpable homicide, as the charge is now restricted. You can return a verdict of not guilty according as you think the special defence has been made out or if you think that the Crown has failed to prove its case against the accused. You are also entitled, if that is a view which you take, to return a verdict of not proven. I confess to you quite openly and publicly that I do not ever feel happy about verdicts of not proven because, although they are strictly speaking acquittal and can be logically justified, it seems to me the honest and proper thing to do is either find a person guilty or, if the Crown has failed, to acquit them with a verdict of not guilty. But that verdict [not proven] lies open to you, and you can use it if you so wish. ${ }^{79}$

Appeal on the basis of misdirection was permitted because the jury was "strongly discouraged from bringing a verdict of not proven." 80 "They were, in

73. Bill Adam, That Bastard Verdict, 1999 Scot. LAw GAZETTE 159 (citing the Contempt of Court Act 1981, which makes it an offence to question juries on their deliberations).

74. $I d$.

75. $I d$.

76. Id. (quoting LA v. Nicholson, 1958 S.L.T. 17). Juries in Scotland may convict by a simple majority. See WALKER, supra note 14, at 529.

77. Adam, supra note 73 , at 159-60.

78. Id. at 160 .

79. McNicol v. HM Advocate, 1964 J.C. 25.

80. Id. 
effect, left with only two possible choices, when in fact they should have had three." $" 81$

\section{The Thomson Committee}

The first formal consideration of the not proven verdict came in $1975 .^{82}$ Lord Thomson submitted a report entitled Criminal Procedure in Scotland (Second Report) to Scotland's Lord Advocate and Secretary of State, to be presented to Parliament. ${ }^{83}$ The Thomson Committee's findings "ranged over the whole of Scottish criminal procedure and supported the retention of the three verdicts." distinctive features of the Scottish jury," including the not proven verdict, and delivered interrelated recommendations. ${ }^{85}$ Specifically, the committee considered abolition of the three verdict system, because " $[t]$ he not proven verdict came in for considerable criticism from some ... witnesses.,

The Committee used arguments for the abolition of the not proven verdict as the starting point for their review. ${ }^{87}$ The first contention was that the not proven verdict was "illogical and served no useful purpose." 88 The burden of proof beyond a reasonable doubt acted as the foundation for this point of view: "[T]he proper verdict is guilty if the case is so proved: if it is not so proved, the verdict should be not guilty." 89 A second argument upon which the committee relied was that the not proven verdict is "stigmatic." 90

In response to these concerns the committee also reviewed arguments in favor of retention. ${ }^{91}$ In answer to the issue of irrelevancy it was pointed out that the verdict of not guilty can be construed in two ways: as meaning "not proved guilty" or as "innocent." effect," differentiating it from a mere lack of satisfaction of proof beyond a reasonable doubt. ${ }^{93}$ Furthermore, the concern over stigma was rebutted with the submission that if the not proven verdict were abolished, "the not guilty

81. Id. Foreshadowing future review, Lord Justice-General Clyde also stated that "no convincing argument has been advanced to justify [the not proven verdict's] elimination from our law." Id.

82. See Gow, supra note 23.

83. SCottish Home and Health Department and Crown OfFice, Criminal Procedure IN SCOTLAND (SECOND REPORT), 194-99 (1975) [hereinafter Thomson Report].

84. Ian Willock, The Verdict Muddle - A Way Out, SCOLAG J., Jan. 1993, at 5.

85. Thomson Report, supra note 83, at 194.

86. Id.

87. Id.

88. Id.

89. Id.

90. Id.

91. Id.

92. Id.

93. Id. The committee was not willing to "go so far" as to flatly agree with this contention, although it admitted that the concept did affect their reasoning to some extent. Id. at 195. 
verdict would acquire a stigma which it does not have."94 Additionally, the argument was made that "if juries were faced with a straight choice between guilty and not guilty, they would in some cases return verdicts of guilty where they would have found the case not proven if that verdict had been open to them." 95

In making their recommendation to keep the three verdict system, the Thomson Committee, "[i]n fairness to the accused ... prefer[ed] to retain the not proven verdict." 96 They made clear that there was "no evidence that the public regard the present system as working unsatisfactorily," and that they did not "wish to make any recommendation which might possibly have an adverse result." $"$ The Committee also stated that the criticism that two acquittal verdicts is illogical may be founded on the fact that few judges distinguish them from each other. ${ }^{98}$ However, the Committee was also quick to point out that the "wisest and certainly the safest course for a judge to follow" is not to attempt to draw a distinction between not proven and not guilty in directions to the jury. ${ }^{99}$

This advice was put into practice for more than a decade following the Thomson Committee's report, as evidenced by the cases of McDonald v. HM Advocate and Fay v. HM Advocate, where the sentiment that judges should exercise restraint in charging the jury was reiterated. ${ }^{100}$ In McDonald, like McNicol before it, the issue on appeal was the instruction given to the jury regarding the differences among the three verdicts:

You say where does not proven come, well where indeed? It is not easy to define the not proven verdict .... [I]f the not proven verdict was not available your verdict almost certainly would be guilty .... You have a niggling concern at the back of your mind that you do not want to let the accused person free and without stain on his character, yet you are unhappy about the quality and standard ... of the Crown['s] evidence. $^{101}$

94. Id. at 194.

95. Id. at 195.

96. Id. at 195. The recommendation was not unanimous, however, because three committee members remained opposed to retention of the not proven verdict on grounds that the report was a "formal recognition of what might be described as first and second class acquittals." Id. at 195.

97. Id. at 197. "It almost goes without saying that the Committee possessed no information whatsoever about the way in which the not proven verdict was understood and used by juries." Duff, supra note 13, at 7 .

98. Thomson Report, supra note 83, at 195.

99. Id. See also McNicol v. HM Advocate, 1964 J.C. 25.

100. McDonald v. HM Advocate, 1988 J.C. 74; Fay v. HM Advocate, 1989 J.C. 129.

101. McDonald, 1988 J.C. 74. Sheriff Fraiser claimed that his direction was "quite deliberate" and was one that he had "commonly given," having derived it from the comments of Lord Justice-General Clyde in McNichol. Id. 
The resulting convictions were quashed, and the court allowed an appeal because the "direction on the not proven verdict was a misdirection."102 Furthermore, Lord Dunpark stated that the sheriff "would be well advised to stop giving [such jury instructions]," because it is "highly dangerous to ... endeavor to explain what the not proven verdict is in relation to the not guilty verdict." 103

The effects of McDonald perpetuated ignorance on the part of the public, specifically jury members, ${ }^{104}$ and resulted in a "positive disinclination on the part of the judiciary to provide any sort of direction on the applicability of the verdict and, by way of precedent, to sheriffs and judges hearing subsequent trials." 105 Less than a year later in Fay, after a direction for the jury to find "not guilty" if they decided the accused was innocent, counsel argued that the necessary implication was that "not proven" applied where the jury considered the accused not innocent. ${ }^{106}$ The court held the argued implication erroneous, and suggested that if the sheriff had been aware of the decision in McDonald, perhaps he would not have "attempted to draw the distinction between these two verdicts." 107 Ultimately, the court found that no miscarriage of justice had resulted, and the appeal was denied. ${ }^{108}$

Some, however, did not agree with limiting the instruction concerning the two acquittal verdicts. ${ }^{109}$ In his commentary on Fay, Sheriff Gordon expressed that "[e]ither there is a statable [sic] difference between not proven and not guilty, in which case the jury are entitled to be told what it is, or there is no such difference between them, in which case one of them should be abolished."110

\section{Amid the Muddle $e^{111}$}

Perhaps because the contradictions among the three verdicts had become more glaring, during the early 1990 s, the not proven verdict again came under scrutiny, while the Thomson Committee's report lost following. ${ }^{112}$ One

102. Id.

103. Id. "[T] $]$ he normal direction is to say you have three verdicts, one of guilty and two alternative acquittal verdicts of not guilty or not proven[,] and to say to the jury the choice is theirs because they are both acquittal verdicts." Id. "[J]urors generally received no guidance whatsoever on how they should differentiate these two verdicts." Duff, supra note 13, at 6.

104. See Adam, supra note 73, at 159.

105. Id. at 160 .

106. Fay v. HM Advocate, 1989 J.C. 129.

107. Id. The court does point out that "[i]n fairness to the sheriff . . . the decision in McDonald was not reported until after the date of the trial in the present case." Id.

108. Id.

109. See Willock, supra note 84 .

110. Id.

111. Id.

112. Id. 
example of this is found in Larkin v. HM Advocate, ${ }^{113}$ concerning jury instructions like McNicol and McDonald. The sheriff's charge was:

On the evidence which we have heard, you will be quite entitled to find each of them guilty; again on the evidence which you have heard, you would be quite entitled to find each of them not guilty; and again it may be that the words "not guilty" might just stick in your throats and you could not bring yourselves to utter them but nevertheless felt the charges have not been proved fully to your satisfaction, then again, if that was so, a verdict of not proven would be appropriate. ${ }^{114}$

In sharp contrast to previous cases, the court held that the sheriff "was doing no more than telling the jury of the place which the not proven verdict occupies in our legal procedure." "Is It was inferred from this case that appellate judges were "ready to countenance the older practice" of drawing a distinction between the two acquittal verdicts in jury instructions, which had been criticized since the Thomson Committee report. ${ }^{116}$

Another reason for the scrutiny of the not proven verdict was several cases where the verdict "caused great dissatisfaction and feelings of injustice from members of the victim's family." "17 One such case involved a 19-year-old charged with stabbing another teenager to death during a gang fight, and who was acquitted after a not proven verdict. ${ }^{18}$ Another involved the acquittal of a man charged with murdering a taxi driver by stabbing him through the heart with a hunting knife. ${ }^{119}$ A third case, the sexual assault and murder of a nineteen-year-old student named Amanda Duffy, also resulted in the accused, Francis Auld, going free after a verdict of not proven. ${ }^{120}$

Well publicized and arousing considerable public controversy, the verdict in the Duffy case was perhaps the most politically significant. ${ }^{121}$ Most observers were astonished by the verdict, because "[t]he impression given by the media was that the accused had indeed committed the crime." 122 The "considerable forensic evidence" 123 seemed overwhelming: a bite mark on Duffy's breast was shown to have been inflicted by Auld; a clump of hair found near the body was matched to Auld's; and Auld's alibi was not corroborated. ${ }^{124}$

113. Larkin v. HM Advocate, 1993 S.C.C.R. 715.

114. Id.

115. Id.

116. Ian Willock, Not Proven, SCOLAG J., Sept. 1993, at 142.

117. Gow, supra note 23.

118. Id.

119. Id. (discussing Mullan v. Anderson, 1993 S.L.T. 835).

120. Id.

121. Duff, supra note 13 , at 7.

122. Id.

123. Alistair Bonnington, Private Prosecutions, 145 NEw L. J. 1105 (1995).

124. Adam, supra note 73, at 159. 
The impression given by police was that the matter was closed, as far as they were concerned. ${ }^{125}$

This case, as well as the others in which a "seemingly incomprehensible not proven verdict had been returned, led to the "Abolish the Not Proven Verdict Campaign'."126 Duffy's parents organized a petition within weeks of the decision. ${ }^{127}$ The petition quickly carried approximately 38,000 signatures and was "circulated nationally throughout Scotland." 128 One commentator stated that it was somewhat odd that this "populist movement" should be "complaining that the acquitted accused has been denied the verdict of not guilty and in the eyes of many people leaves the court under a cloud of suspicion." ${ }^{29}$ He went on to say that "the point the campaigners are making is well taken .... 'We have got three verdicts in Scotland and two of them mean the same thing.","130

Early in the campaign, the Duffys secured the assistance of George Robertson, their representative Member of Parliament (MP). ${ }^{131}$ This not only helped their cause gain further momentum, it also allowed it to "climb the political agenda" 132 when Robertson introduced a private member's bill to abolish the not proven verdict. ${ }^{133}$ Robertson said that the verdict was "equally unfair to the accused, for whom it is seen as 'guilty but not enough proof,' and the victim and victim's family, who are left only with a question mark and no resolution of a crime." 134 The political pressure became enough for the Lord Advocate, the senior law officer in Scotland, to reveal that he felt some "unease" about the not proven verdict. ${ }^{135} \mathrm{He}$ also suggested that "if one were designing a legal system from scratch, one would not incorporate a three verdict system." ${ }^{136}$ The Scottish Office made a statement at the same time as the Lord Advocate, saying that it "'was not convinced that there was enough groundswell of dissatisfaction from the public and, crucially, from the legal profession' to justify any scrutiny of the not proven verdict.,"137

Less than two months later, following and fueling the public's outcry, British Broadcast Company (BBC) Scotland devoted a documentary television program to the issue. ${ }^{138}$ They also commissioned a public opinion poll. ${ }^{139}$ Of

125. Duff, supra note 16 , at 195.

126. Adam, supra note 73 , at 159 .

127. Duff, supra note 13 , at 7 .

128. Gow, supra note 23.

129. Willock, supra note 84.

130. Id. Willock also suggests, "They have obviously been well instructed by their lawyers and find what they have been told incomprehensible." Id.

131. Duff, supra note 13 , at 7 .

132. Gow, supra note 23 .

133. Duff, supra note 13 , at 7 .

134. Gow, supra note 23 .

135. Duff, supra note 16 , at 195.

136. Duff, supra note 13 , at 8 .

137. Id. at 8-9.

138. Duff, supra note 16, at 196 . The documentary program, entitled Not Proven: That 
those questioned, " 48 per cent ... [erroneously] believed that, after a verdict of not proven, the accused could be retried on the same charges if fresh evidence emerged. ${ }^{140} \mathrm{~A}$ further 11 per cent simply did not know the consequences of such a verdict." 141 As such, it appeared that " 60 per cent of the Scottish public-and, consequently, potential and actual jurors-simply did not understand the not proven verdict."

Days after the BBC documentary aired, Robertson secured a meeting with the Secretary of State for Scotland, Ian Lang, to discuss his private member's bill for abolition of the not proven verdict. ${ }^{143} \mathrm{~A}$ week later, having garnered approximately 60,000 names, the Duffy family presented their petition to the Scottish Office. ${ }^{144}$ The next day, in a turn-around from the position taken two months earlier, Lang announced a "wide-ranging review" of the Scottish criminal justice system and made a "surprise pledge" to include "scrutiny of the not proven verdict along with various other aspects of trial by jury." 145 It was touted as "the biggest review of the criminal justice system north of the border [with England] in nearly 20 years."

\section{Improving the Delivery of Justice in Scotland ${ }^{147}$}

"[D]espite the fact that the question of the not proven verdict was clearly tangential to the main thrust of the review, the debate over the three verdict system overshadowed all the other matters under consideration" by the Scottish Office. ${ }^{148}$ The starting point for the review was actually the "perceived waste of time by civilian and police witnesses waiting to be called,"149 and the "primary motive ... was to cut costs and increase efficiency."150 Four consultation papers were published in preparation for the review, the third of which was the

Bastard Verdict, was "essentially hostile to the retention of the three verdict system," and featured the Duffy case and Robertson. Duff, supra note 13, at 9.

139. Duff, supra note 13, at 9.

140. Id. "This is indicative of the failure of the lawyers in court to get the proper message across to the 15 people who make up a Scots criminal jury." Alistair Bonnington, The Jury - A Suitable Case for Treatment?, 145 NEw L. J. 847 (1995).

141. Duff, supra note 13, at 9.

142. Id. "There was no difference in knowledge between those who had been on a jury and those who had not." Id.

143. Id.

144. Id. The Duffy family also brought a civil case for damages against Auld, a fairly rare event in Scotland. See Bonnington, supra note 123. In this "second line of prosecution" the standard of proof is "balance of probabilities" [similar to more likely than not] as compared to "beyond reasonable doubt." Id. The pleadings "quite openly accus[ed] him" of their daughter's killing, and Auld was advised not to defend the case. Id.

145. Duff, supra note 13, at 10 . By coincidence, the Scottish Office had been planning the review during this same period, entitling it "Improving the Delivery of Justice in Scotland." Id.

146. Scottish Review, L. Soc'y GAZETTE, June 2, 1993, at 7.

147. See supra note 145.

148. Duff, supra note 13 , at 10.

149. From the Editor - Criminal Justice on Trial, 38 J. L. Soc'Y. Scot. 286 (1993).

150. Duff, supra note 13, at 10. 
only one "not primarily concerned with issues of cost and efficiency."151 Entitled Juries and Verdicts, it raised several issues affecting the jury system, although "the bulk of the paper-six out of [twelve] chapters-was devoted to the not proven verdict." 152 The purpose of this consultation paper was not to express an opinion on the future of the three-verdict system, but to simply canvass the arguments for abolition or retention and invite the submission of views from the public. ${ }^{153}$

In light of the public movement to abolish the not proven verdict, the Scottish Office introduced Juries and Verdicts with a "unifying theme": "[A] high priority to maintaining the quality of our system of justice and recognis[ing] that, to achieve this, it is essential that the system must have the support of the public at large." 154 As with the Thomson Committee report of 1975 , it is "interesting to note the importance apparently attached to public opinion, for that, of course, is precisely the audience with which trial by jury is primarily concerned." 155 This assertion is based on the idea that the jury "performs an ideological or symbolic role in the criminal justice process" that may be "more significant than the impact the jury has in practice.", 156

From a practical standpoint, the "question of what verdicts are available and how they should be used must be of substantial interest to citizens who are asked to serve on juries." 157 Yet, the Scottish Office did not hesitate to point out that " $[\mathrm{t}] \mathrm{here}$ is no statutory, case law or generally accepted definition of the not proven verdict, nor of the difference between not proven and not guilty." 158 Furthermore, the consultation paper did not take a position on the issue of the directions to juries. ${ }^{159}$ Regardless of this lack of definition, at the time of Juries

151. Id.

152. Id. at 10-11.

153. Id. at 11 .

154. JURIES AND VERDICTS, supra note 28 , at 5.

155. See Duff, supra note 13 , at 7 .

156. Id. at 1. In Scotland, fewer than one percent of those brought to trial in a criminal court have a jury. Id. Duff proposes that "what [the jury] achieves in the realm of ideology" is most important:

[I]t represents to the public an adherence by the state to a mélange of aims and ideals which buttress, in particular, the legitimacy of the criminal justice system and, in general, the democratic system of government. The jury acts primarily as a symbol: it symbolizes impartial and independent decision making in the criminal justice process; and, in the broader context, it symbolizes community representation and participation in the process of government. Through its ideological role, the jury helps obscure the reality of the criminal justice system which primarily involves the routine processing of large numbers of guilty pleas through the lower courts. In essence, therefore, the jury acts primarily as a flagship or showpiece for the criminal justice system.

Id. at 2 .

157. JURIES AND VERDICTS, supra note 28 , at 6.

158. Id. at 29. "The most common popular explanation," it says, "is that not guilty means that the accused did not commit the crime, whereas not proven means that there was a reasonable doubt as to whether he did commit the crime." Id.

159. Id. at 30. 
and Verdicts, usage of the not proven verdict accounted for twenty-one percent of acquittals. 160 Juries tended to "make proportionately more use of the not proven verdict," returning it in a higher percentage than sheriffs and justices alone. $^{161}$

The Scottish Office also hoped to clear the air by responding to "misconceptions" the public had concerning the not proven verdict. ${ }^{162}$ Their expectation was that erroneous views about the "nature and effect of the [not proven] verdict" "63 would be corrected by Juries and Verdicts. ${ }^{164}$ First, clarification was given concerning the issue of double jeopardy, pointing out that it would be "unfair and oppressive" to "bring fresh proceedings when a court has decided that [the Crown] has failed to bring its case." 165 Additionally, perhaps in answer to the attitude displayed by police in the case of Amanda Duffy, ${ }^{166}$ it was put forth that the not proven verdict does not "prevent anyone else [from] being convicted for [the same] crime." 167 Lastly, the Scottish Office contended that the not proven verdict was not a "soft option" allowing juries to "avoid their duty to reach a clear verdict" when they were "reluctant to convict," because it is a "clear decision to acquit" and "is in its effects the same as a not guilty verdict." 168

With these issues aside, the debate over the not proven verdict began again, enlarged since the Thomson Committee's report, and with the purpose of the government welcoming views on whether to retain the three verdict system. ${ }^{169}$ Abolitionists' concerns over the presumption of innocence were

160. Id. at 27.

161. Id. However, "because of the far greater number of summary prosecutions, $88 \%$ of not proven verdicts are returned by sheriffs or justices sitting alone." Id.

162. Id. at 31 .

163. Id.

164. Duff, supra note 13 , at 11 ; see also ScOTTISH OFFICE, FIRM AND FAIR: IMPROVING THE DELIVERY OF JUSTICE IN SCOTLAND 19 (HMSO, Edinburgh Press 1994) [hereinafter FIRM AND FAIR]. Duff considers this a "rather unrealistic view," stating, "Obviously, such statements amount to no more than wishful thinking; the bedtime reading of the Scottish public - and, thus, potential jurors-is hardly likely to include Scottish Office consultation papers on criminal justice." Duff, supra note 13, at 11.

165. JURIES AND VERDICTS, supra note 28, at 31 . Almost patronizingly, the Scottish Office states that "this has been the rule for as long as criminal proceedings have been documented in this country." Id.

166. See Duff, supra note 16, at 195.

167. JURIES AND VERDICTS, supra note 28 , at 31.

168. Id. at 32 . The acquitted "are not subject to any sanctions, restrictions on their liberty or loss of rights. Since they have not been proved guilty they should be presumed innocent." Id. at 35 . "If the not proven verdict were not available, then in logic juries should choose not guilty in its place." Id. at 32 . However, logic is not always the deciding factor where a jury may find that "the law needs to be tempered with mercy." Duff, supra note 16, at 195. For example, a jury may know "perfectly well the accused is guilty [but], it is not prepared to convict in [a] particular case." Id. This provides the jury with "a rather subtle way of 'nullifying' the law instead of having to confront it directly and openly." Id. Cf. discussion supra Part II.A.4 (discussing early cases in which the jury avoided imposing a guilty verdict).

169. JURIES AND VERDICTS, supra note 28 , at 37. 
addressed directly. ${ }^{170}$ The Office suggested that the not proven verdict is consistent with this presumption because a "trial is held to establish whether the Crown's case is proved beyond reasonable doubt," and "not necessarily [to] provide an opportunity for an accused person to establish his innocence." "171 "It is only in any social stigma" it was acknowledged, "that this presumption may be weakened." $" 172$

In this regard, the criticism that the not proven verdict "leaves the character of those who are subject to it stained in some way" was cited as one of those "most consistently expressed." 173 While admitting that "[i]n some cases reporting of the evidence against the accused clearly does stigmatise him whatever the verdict," and that "two different acquittal verdicts may increase the possibility of stigma," the Office believed that it was "not necessarily a conclusive argument against the three verdict system." 174 A more powerful argument concerned the "lack of clarity and scope for confusion" acting as a disadvantage to the three-verdict system. ${ }^{175}$ Instead of promoting ignorance like the Thomson Committee, the Scottish Office claimed it was unsatisfactory for juries and judges to use an unexplainable verdict, without criteria for choosing between the two acquittals. ${ }^{176}$

The effect on victims and their families was also discussed, perhaps another reference to the case of Amanda Duffy and its aftermath. ${ }^{177}$ The Office recognized that trauma could be eased by a conviction, or could be exacerbated by acquittal. ${ }^{178}$ "However, it is not clear that the returning of a not proven verdict is any more unsatisfactory for the victim and family than a not guilty verdict," which "would be the logical alternative."179

Juries and Verdicts also covered the arguments in favor of retention. ${ }^{180}$ The "principle justification" listed for having a third verdict was that "it provides an additional outlet for reasonable doubt." "The not proven verdict was considered a "safeguard which allows judges and juries to express their reasonable doubts in a manner acceptable to them," rather than deciding guilt

170. Id. at 35. "The usual reason given for abandoning not proven is that it is incompatible with the presumption of innocence. But it should be stressed that that is a gloss on the burden of proof which lies throughout on the Crown." Willock, supra note 84.

171. JURIES AND VERDICTS, supra note 28 , at 35.

172. Id.

173. Id.

174. Id. at 36 .

175. Id.

176. Id. Perhaps because it was "born in a collective moment of total belief in a man's innocence, [the not proven verdict] has never been allowed to fully develop. Unless sheriffs and judges are allowed to give opinions on what it means and when it is applicable it never will." Adam, supra note 73, at 160.

177. See JURIES AND VERDICTS, supra note 28 , at 36.

178. Id. at 36 .

179. Id. at $36-37$.

180. Id. at 33 .

181. Id. 
on the basis of not wanting to assign innocence. ${ }^{182}$ Secondly, and more esoteric, the Scottish Office said, "the availability of the not proven verdict is a pragmatic recognition of reality." 183 It "evolved from the will of the people and is in keeping with the common law foundation of much of Scotland's criminal justice system." 184

Although denying a connection in law between the Scottish requirement for corroboration of evidence ${ }^{185}$ and application of the not proven verdict, the Office did suggest that concerns over the credibility of victims and witnesses were important. ${ }^{186}$ One implication drawn was that the not proven verdict "is a more satisfactory verdict for the victim and others ... because it can reflect the absence of the necessary proof without casting doubt on the honesty or reliability of the victim."187

In the conclusion of Juries and Verdicts, the Scottish Office presented the choice of a two verdict system: guilty and not guilty as opposed to proven and not proven. ${ }^{188}$ It proposed that objections to the not proven verdict could also support the abolition of the not guilty verdict. ${ }^{189}$ "There is an argument that the available verdicts should be proven and not proven since this reflects the real purpose of criminal trial which is to establish whether [the case is proved] beyond reasonable doubt and not to prove guilt or innocence per se."190 The benefit of being found not guilty, which would lessen stigma and support the perception of presumed innocence, was a factor in favor of using the guilty/not guilty verdicts. ${ }^{191}$

The result of the paper, as anticipated, was an enlivened debate over proposals to improve the three-verdict system of jury trials in Scotland. ${ }^{192}$ One barrister said, "There is no real place for having two separate verdicts of acquittal .... If there is full and proper argument, it is [difficult] to justify retaining the verdict." 193 Another stated that the value of the not proven verdict

182. Id. "This third alternative is also considered to be a valuable safeguard against unjustified verdicts of not guilty." Linda Tsang, Separate Verdicts, LAWYER, June 27, 1995, at 16.

183. JURIES AND VERDICTS, supra note 28, at 33.

184. Id. See also supra note 156 (discussing the connection between the public and jury trials).

185. See WALKER, supra note 14 .

186. JURIES AND VERDICTS, supra note 28, at 33.

187. Id. at 33-34. "This advantage is particularly relevant to serious sexual offences where it may be that the victim is the only witness and there may be insufficient corroboration." Id.

188. Id. at 38.

189. Id. "Indeed, to straighten out the whole mess the guilty verdict should be replaced with 'proven.' That would be a departure from common usage in the rest of the English speaking world, but it would make manifest to it the independent and logical outlook of Scots law." Willock, supra note 84.

190. JURIES AND VERDICTS, supra note 28 , at 38 . This choice would also reflect seventeenth-century history. See discussion supra Part II.A.2.

191. JURIES AND VERDICTS, supra note 28, at 38.

192. Id. at 5 .

193. See Tsang, supra note 182 (quoting Gordon Jackson, QC). 
was that "when the jury is confronted by evidence of varying types and characters, it can return a verdict which more closely reflects their view of the case .... It enables a jury to concentrate on the quality of the evidence they are there to determine." 194

Sir Nicholas Fairbairn, Queens Counsel (QC) and Member of Parliament, also added his two pence, because "the Lord Advocate has asked for comment." 195 He considered the verdict "not a let out verdict as is often claimed," but rather "the proper verdict where the jury are not satisfied beyond reasonable doubt but cannot say not guilty."196 "So what is wrong with a ranch of verdicts which provide for all situations?" he asked, answering: "Nothing I can see, so I find the case against not proven, not proven. Long live 'Not proven.",197

The Scottish Office agreed, and kept the not proven verdict. ${ }^{198}$ In June of 1994, the government published a White Paper entitled Firm and Fair, ${ }^{199}$ derived from the responses to the four prior consultation papers, including Juries and Verdicts. ${ }^{200}$ Although the Scottish Office determined that Scotland was "well served by its distinctive system of criminal justice," it was clear that a "substantial overhaul" through "significant reforms" was to take place. ${ }^{201}$ "We have taken careful account of [the replies to the consultation papers]," the Secretary of State for Scotland wrote, "and they have helped to shape proposals in this White Paper. Our aim is to produce a system which is fair to all - to victims, to witnesses and to society at large, as well as to the accused."202

Even so, of approximately seventy proposed changes, no plans were included for altering the three-verdict system. ${ }^{203}$ The Office explained that the three-verdict system should not be altered or abolished lightly, at the same time it should not be maintained out of tradition. ${ }^{204}$ To split the difference, the

194. Id. (quoting Donald Findlay, QC). While the debate was happening, in 1993 the not proven verdict was brought 1,515 times (approximately one percent of scheduled trials), and ten times out of 118 for murder. Id.

195. Sir Nicholas Fairbairn, The Not Proven Verdict, 37 Scot. L. TIMES 367, 367-68 (1994). He prefaced his comments by saying that "the reasons for the assaults upon [the not proven verdict] are that it is different and thoughtfully civilised." Id.

196. Id.

197. Id. at 368 .

198. See Duff, supra note 16 , at 196.

199. See FIRM \& FAIR, supra note 164.

200. Duff, supra note 13, at 11.

201. FIRM AND FAIR, supra note 164 , at v.

202. Id. The Secretary of State for Scotland also emphasized:

We must have a criminal justice system which works, and is seen to work, well.

It must be understood by those who pay for it, and who look to it to protect them, their families and the communities in which they live .... It is essential that the Scottish criminal justice system commands respect and public confidence.

Id. at v, vi. This supports Duff's view of the symbolic importance of the jury. See supra note 156.

203. Duff, supra note 13 , at 11.

204. FIRM AND FAIR, supra note 164 , at 19. 
Office sought "a consensus for change" among the public or the legal profession, which the responses to the consultations had not revealed. ${ }^{205}$ For example, responses were divided as to the logic of the not proven verdict, with some supporting the view that three verdicts were "more consistent with reality than a two verdict system." 206 Without "a considerable weight of informed opinion against the verdict" the Office retained it. ${ }^{207}$

Yet the debate continued among the public, as well as the members of the House of Commons. ${ }^{208}$ A year after Firm and Fair, John Home Robertson, Member of Parliament for East Lothian, proposed that "[i]n any criminal proceedings the verdict of not proven shall no longer be competent," and pushed for a vote on the issue. ${ }^{209}$ "I cherish Scotland's institutions and its traditions, and perhaps our national idiosyncrasies, but it is abundantly clear to me that this particular example [the not proven verdict] is far more bother than it is worth," he said, continuing, "It is making real mischief and devaluing the quality of Scottish justice."210

Robertson's main concern with the verdict, which he considered a "comprehensive cop-out," was the "indelible smear" it leaves on the character and record of the acquitted person. ${ }^{211}$ "In theory, he has been acquitted, but it is fair to assume that his reputation is blemished, and that his career is likely to be affected .... He is not guilty but, after that verdict, he is not innocent, either." 212 Robertson also termed the verdict a "grudging acquittal" for which there is no logical basis, because "[i]t simply creates the odd phenomenon of either qualified innocence, which carries a stigma ... or qualified guilt, which carries no penalty." $" 213$ It was this anomaly he wanted addressed in a way more satisfying than the review culminating in Firm and Fair. ${ }^{214}$ "The not proven verdict may be a rather quaint Scottish tradition, but I submit that nostalgia cannot be a sound basis for good justice," he concluded. ${ }^{215}$ "The not proven verdict is a device for sidestepping justice and has been tolerated for far too long .... It is a formula which should be consigned to history."216

205. Id. See also Duff, supra note 16 , at 196.

206. FIRM AND FAIR, supra note 164, at 19; see also JURIES AND VERDICTS, supra note 170.

207. FIRM AND FAIR, supra note 164, at 19. This echoes the Thomson Committee's conclusion. See supra note 97 and accompanying text.

208. Hansard, supra note 25 , at 219.

209. Id. He was hopeful that the House of Commons would address the problem, realizing that "[t]he House is the only place where it can be addressed until such time as we have a Scottish Parliament." Id. at 237.

210. Id. at 219.

211. Id.

212. Id. at 237.

213. Id.

214. Id. Of the prior review, he noted: "It looks to me as if the Government [has] copped out of the opportunity to deal with Scotland's cop-out verdict." Id. at 221 .

215. Id. at 220 .

216. Id. at 220-21. 
George Robertson, Member of Parliament for Hamilton, who was involved with the Duffy family's petition from its early stages, had strong personal views on the subject. ${ }^{217}$ His main argument addressed the confusion resulting from the three verdicts, which he believed led to an "undermining of faith in the Scottish criminal justice system" even after Firm and Fair. ${ }^{218}$ As emblematic of that confusion, he set forth the formal titles of the verdicts, different from those understood by the general populace: "Acquitted Not Guilty, Acquitted Not Proven, Charge Proved."219 "If there is such confusion about the terminology of the verdicts in the courts," he said, "it is not surprising that there is some confusion among the general population."220

He also pointed to the lack of instruction for jurors. Because the "sheriffs or judges often do not make clear the differences between the three verdicts.... it is scarcely surprising that members of the public, as well as jury members, are confused."221 Such confusion "cannot be good for the reputation, integrity and efficacy of the criminal justice system in Scotland." ${ }^{222}$ Robertson summed up his position by asking, "Who at the end of the day is still in favour of three verdicts in the Scottish courts:"223

Not the victims, who are left hanging in the air of frustration and mystery that comes at the end of a trial when a not proven verdict is handed down. Certainly not the recipient, unless he or she was guilty and is relieved at having been acquitted, because the recipient is left with a stigma, which . . . is impossible for him or her to clear. The system cannot be satisfied with a situation that undermines the presumption of innocence. The public, who are at best confused by, and at worst hostile to the idea of the not proven verdict, certainly are not in favour of having three verdicts. The legal profession may well be, especially those who are in criminal cases on the defence side, because it is an entirely suitable deployment of their skills to go for three verdicts instead of just two. Those who were clearly guilty but feel that they have got off could be in favour of it as well .... [J]uries who do not want to take a straightforward decision based on the case that has been put before them will be pleased to have three verdicts in Scottish courts. $^{224}$

217. Id. at 228.

218. Id. at 229.

219. Id.

220. Id.

221. Id.

222. Id. at 230 .

223. Id. at 234.

224. Id. at 234-35. 
On balance, he considered these to be "a sufficient strength of opinion to weigh against the arguments" for retaining the not proven verdict. ${ }^{225}$

But other Members of Parliament, such as Malcom Chisholm of Edinburgh/Leith, voiced opposition to abolishing the not proven verdict. ${ }^{226} \mathrm{He}$ did so with what he considered the "majority of informed opinion in Scotland," including "the massed ranks of the judges of Scotland, the Law Society of Scotland, the Faculty of Advocates, the Scottish Council for Civil Liberties and the rape crisis centres and victim support organizations in Scotland," as well as the Scottish conference of the Labour party. ${ }^{227}$ One point he argued was, "[i]f we were to get rid of everything that is confusing in the Scottish legal system, we would dismantle quite a lot.",228

Menzies Campbell, MP of Fife North-East, suggested that such a dismantling would have "profound and far-reaching consequences" though it may seem right superficially. ${ }^{229}$ Relying on Juries and Verdicts and Firm and Fair, he posited that the criticisms of the verdict were based on misconceptions of its nature and effect. ${ }^{230}$ Rather than viewing it simplistically, Campbell stressed that "the not proven verdict . . . is a sophisticated verdict in a sophisticated legal system." most appropriate may not be capable of scientific prediction, but the law is not an empirical but a normative discipline." ${ }^{232}$ In this way "[t]he verdict allows juries and [judges] to express a shade of meaning concerning an acquittal different from what they believe would be justified by the use of the words 'not guilty'."233 He further argued that "[a]ny alteration . . . cannot be considered in isolation .... [A]part from the merits of the verdict, one must have regard to its consequences." 234 For example, in a system where an eight to seven vote results in conviction, "the not proven verdict is an important protection in cases in which a simple majority would be sufficient."235

225. Id. at 235 .

226. Id. at 224.

227. $1 d$.

228. Id. at 225.

229. Id. at 221.

230. Id.

231. Id. at 222. He also states:

I understand the occasional outpouring of grief[,] of anxiety, or even outright anger, that arises when a not proven verdict is returned, but sympathy and understanding of those emotions should not blind us to the fact that, in serious cases, decisions about guilt and acquittal are taken by the jurors empanelled for Id. at 223. that purpose, not by the system of verdicts.

232. Id. at 222.

233. Id.

234. Id. at 223.

235. Id. 
In terms of the vote by the House of Commons upon the proposition by John Home Robertson, the majority of members, 325, were for retention of the not proven verdict, while only 117 supported its abolition. ${ }^{236}$

\section{AN OLD VERDICT FOR A NEW MILLENNIUM}

\section{A. Scotland: Getting Off Scot Free $e^{237}$}

"History can explain, but there is no reason why it should dictate current practice, unless there are good reasons to let it do so."238 Despite Firm and Fair, this sentiment beat on in the hearts of Scots lawyers who felt that "ever since its inception the not proven verdict has never fully had the benefit of ... guidance from the common law." ${ }^{\text {,239 }}$ Anticipatory optimism hung in the air prior to the year 2000:

As we do not seem-to trust the judiciary to define the verdict we may, at the dawn of a new millennium and with a new Parliament, have to think the unthinkable. We may have to ask the legislature to enter what should be the preserve of the common law and provide a workable explanation of the verdict. Ask it to enact a clear definition with which sheriffs and judges can charge juries, and direct themselves, as to when it is applicable. By doing this, and hopefully educating the general public in the process, Parliament may also be able to address the stigmatizing effect of the verdict. ${ }^{240}$

Instead came more of the same, the 2001 case of Cussick v. HM Advocate ${ }^{241}$ for instance. Again, the appeal dealt with misdirection concerning

236. Id. at 238.

237. Michael Quinion, Scot free, World Wide Words, Questions \& Answers, at http://www.worldwidewords.org/qa/qa-scol.htm (Oct. 24 1998) (last visited Mar. 24, 2005).

As with the word hopscotch, scot free has no connection with Scotsmen, frugal or otherwise. It's a Scandinavian word meaning "payment". The expression derives from a medieval municipal tax levied in proportional shares on inhabitants, often for poor relief. This was called a scot, as an abbreviation of the full term scot and lot, where scot was the sum to be paid and lot was one's allotted share .... So somebody who avoided paying his share of the town's expenses for some reason got off scot free.

Id.

238. Willock, supra note 84 .

239. Adam, supra note 73, at 160.

240. Id. He continues that developing a working definition may be an impossible task for the Scottish Parliament, since sheriffs and Lord Justice-Generals have tried without success. Id. Instead, he suggests that Parliament may have to "think another unthinkable" and "contemplate abolishing 'that bastard verdict!'” Id.

241. 2001 S.L.T. 1316. 
use of the not proven and not guilty verdicts. ${ }^{242}$ Attempting to differentiate between the two, the sheriff said that not proven could be brought if guilt had not been established, but that not guilty would result if the accused had "exculpated themselves from the charge," clearly undermining the presumption of innocence. ${ }^{243}$ The court stated that it had "repeatedly discouraged" such attempts at explanation, and finding it "liable to confuse the jury," quashed the conviction. $^{244}$

A similar situation rekindled the debate in 2002 , when a woman requested that her drugs conviction be overturned based on misdirection. ${ }^{245}$ Once again, the logic of the three-verdict system came under scrutiny. ${ }^{246}$ The dynamics of the argument shifted a degree, however, and seemed more intense than during the consultation paper of a decade earlier, though still geared toward an either/or preference for two verdicts: "'Guilty/Not Guilty' can be justified in logic, as can 'Proven/Not Proven.' 'Guilty/Not Guilty/Not Proven' cannot." 247 Commentators scoffed at the idea that "this [was] just a minor legal technicality." 248 "The verdict is not a mere frill or an appendage to the criminal law in Scotland. It is the business end of the criminal justice system and everything that happens is intended to lead to it."249 Any leftover pre-millennial optimism dissipated, leaving only blunt logical impatience: "The three verdict system is not evidence of Scots canniness which the rest of the world would do well to copy, but a national embarrassment. The Scottish Parliament should scrap it now." 250

The response, more measured in tone, also showed a slight shift in logic, turning the either/or argument against itself. ${ }^{251}$ It largely posited that the not guilty verdict, rather than the not proven verdict, is "wholly inappropriate" because it "confuses absence of guilt with absence of proof of guilt." 252 Furthermore, "the issue is not Guilt or Not-Guilt," and "[i]nnocence is not an

242. Id. at 1319.

243. Id. The less than convincing excuse the sheriff gave was that in a preceding trial he had found the jury's verdict perverse, so had changed the directions. Id.

244. Id. at 1319-20.

245. See Bennett, supra note 46 (discussing Sweeny v. HM Advocate). The Court of Criminal Appeal restated the warning to another sheriff in 2002, criticized for attempting to draw a distinction. Bruce McKain, Sheriff Criticised Over Jury Address, HeRALD (Glasgow), Jan. 22, 2002, at 9 . One Lord hearing the case stated: "This court has repeatedly made observations on the dangers attendant on exercises such as that by the sheriff in this case." Id.

246. See Bennett, supra note 46, at 97. "Not even Lord Justice General Cooper, one of Scotland's greatest judges could justify it, saying in 1947: 'I should not like to offer a logical justification for the retention of the Scottish verdict of Not Proven." Id.

247. Id. at 98; see also JURIES AND VERDICTS, supra note 28. This statement is similar in tone to that of Sir Walter Scott's proclamation. See supra notes 24, 25 and accompanying text.

248. Bennett, supra note 46, at 97.

249. Id.

250. Id. at 98 .

251. Lord McClusky, Not Proven: A Reply, 17 S.L.T. 148, 148-50 (2002).

252. Id. 
issue in a criminal trial." 253 Rather, the retentionists argued that the "choice of 'Yes' or 'No' is the truly logical choice" for a jury to make. ${ }^{254}$ For them, the question to be asked of the jury should be: "Has the prosecutor proved beyond reasonable doubt that the accused is guilty?" to which an answer of "Yes" or "No" would come, and after which the judge would make a formal finding of guilt or acquittal. ${ }^{255}$ With one swift stroke of reasoning, this contention reverts the jury back to the limited status it held in the seventeenth century. ${ }^{256}$ One is left to wonder how this would affect the symbolic purpose of the contemporary jury. ${ }^{257}$

Even still, absent such a reversion, the not proven verdict is appraised as being "very valuable in certain everyday situations." 258 For example, one such scenario would be "where the victim of a crime is accepted as fully reliable but the only corroboration is provided by evidence that is manifestly bogus."259 The jury may acquit, delivering a verdict of not proven, thus leaving the victim untainted but rejecting the "bogus corroboration."260

As ever, the debate over the three-verdict system continues to concern evidence and the burden of proof. ${ }^{261}$ More specifically, in a time when DNA is seen as the new fingerprint, technology has allowed corroboration through "[f]orensic evidence [as] part of much larger evidence . . . which can help equally or more forcefully to convict or acquit than trace evidence."262

The burden of corroborating evidence is nowhere heavier than in a case of serious sexual offenses. ${ }^{263}$ It is possible in a rape case that the jury could "unreservedly accept the evidence of the woman that she was raped by the accused, but [be] unable to find any corroborative evidence .... A verdict of not proven more accurately shows that sufficient evidence as required by Scots law was not found," rather than that the woman was not believed. ${ }^{264}$

253. Id. at 148. "I simply emphasise that the Crown has to prove guilt: the defence merely seek to show that there is no sufficient proof of guilt." Id.

254. Id.

255. Id.

256. See supra text accompanying notes $41-43$.

257. See supra note 156 and accompanying text.

258. McClusky, supra note 251. In terms of practicality, he quotes Oliver Wendell Holmes as saying: "The life of the law has not been logic: it has been experience." Id. at 150.

259. Id. at 149.

260. Id.

261. See McClusky, supra note 251.

262. Brian McConnell, Doubt and the Forensic Pathologist, 146 NEw L. J. 627 (1996). The author's accounts of pathologists testifying in cases, sometimes aiding to secure a verdict of not proven, lends credence to the role of science in jury determinations, even if the pathologists were sometimes wrong. Id. As he points out, because there is "undeniably room for honest doubt in forensic pathology . . . Scots insist on two-doctor post-mortem examinations." Id.

263. See JURIES AND VERDICTS, supra note 28 , at 34 . Statistics in the consultation paper showed that a "smaller proportion of rape and sexual assault cases result in conviction than other serious crimes," with "a slightly higher proportion of acquittals" through not proven verdicts. Id. See also supra note 187 and accompanying text.

264. McClusky, supra note 251. 
The possibility of the not proven verdict has also provided a justification for courage. ${ }^{265}$ Victims of sexual assault and rape must act with considerable bravery when exposing themselves in open court, where they will have to "give evidence and be subjected to a rigorous and sometimes most unpleasant crossexamination about ... . sexual history."266 Even if the evidence is insufficient on its own to bring down a guilty verdict on the assailant, the victim does not have to face "the horror of seeing him offered the unqualified certificate of good character to which a not guilty verdict would have entitled him."267 An example is where a husband and wife are involved and proof remains a major obstacle. ${ }^{268} \mathrm{~A}$ not proven verdict has been returned in at least two such recent cases. ${ }^{269}$ It is speculated that juries may not be satisfied with proof of lack of consent by the wife, and are "operating [under] an implied presumption of consent" between husbands and wives. ${ }^{270}$

It is also argued that "[i]f the not proven verdict is taken away and such verdicts . . . become not-guilty verdicts, the credibility, honesty and reliability of women will be further called into question." ${ }^{271}$ Furthermore, Scottish rape crisis organizations point out that "[i]f women know [the not proven] verdict is not available, it will not only be a serious problem for victims of rape[,] but women will be discouraged from coming forward with complaints of rape."272 However, the view that "rape victims should be happy that such a verdict leaves a stigma behind" is tenuous. ${ }^{273}$ This would be limited consolation if the accused is acquitted at the end of a trial, ${ }^{274}$ even if it is a pragmatic recognition of reality. ${ }^{275}$ Instead it is more likely that "having the cop-out [of the not proven verdict] relieves juries, especially in rape trials, of the obligation of coming to a firm conclusion on what they have heard in court."276

265. Hansard, supra note 25, at 222.

266. Id. at 222-23.

267. Id. at 223.

268. Daniel Kelly, The Reassessment of Rape in Marriage, 35 J. L. SoC'Y. SCOT. 89 (1990).

269. Id. See also Husband and Wife Rape Appeal, 139 NEw L. J. 356 (1989).

270. Husband and Wife Rape Appeal, supra note 269.

271. Hansard, supra note 25, at 226.

272. Id.

273. Id. at 225 .

274. Id.

275. Id. at 226 .

276. Id. at 234 . This seems to have been the case recently, when a 13 -year-old rape victim was told, "There is not enough evidence to show, on the balance of probabilities, that you were the victim of sexual assault." Marion Scott, Fury as Raped Girl, 13, Fails to Win Criminal Compensation, SUNDAY MAIL (Scot.), Jan. 92005 , at 23. While the girl claimed she had been "raped by a stranger on the garden path of her home," the defense argued that the girl-a virgin who had never had a boyfriend-agreed to sex. Id. "The jury returned a not proven verdict on the rape charge" even though the attack took place just sixty-seven days after the girl's thirteenth birthday, prior to which the attacker would have been convicted of statutory rape. Id. One child abuse campaigner said, "[T]his traumatised girl has been raped all over again by the system supposed to help her." Id. Hardly seeming content with a potential stigma imposed on 
In May of 2003, the not proven verdict made its way back into Scottish newspaper headlines. ${ }^{277}$ Tina McLeod, a former child-minder accused of murdering a child under her care by shaking him, was acquitted with the verdict in a highly emotional trial. ${ }^{278}$ The charges came as "an entire shock to everyone around her.",279 "A jury of nine women and six men returned the verdict after hearing conflicting evidence from medical experts about how the child could have died." ${ }^{280}$ One pediatric pathologist suggested that the boy's injuries were consistent with death from violent and repeated shaking, rather than with falling as claimed by the defense. ${ }^{281}$

McLeod felt "in no way inhibited by the not proven verdict," for which she sobbed a "thank you" to the jury in the courtroom. ${ }^{282}$ "When the verdict was given, it meant to me that they believed in my innocence, that they believed in me," she said. ${ }^{283}$ She also stated, "I do not personally feel it [the not proven verdict] has left a cloud over me. I honestly do not think it would make a difference if it had been not guilty." 284

The dead child's parents were less content. ${ }^{285}$ They felt that "the Scottish criminal justice system [had] failed."286 "This verdict leaves us deeply dissatisfied because the question of what happened to Alexander remains unresolved. ${ }^{, 287}$ Their words echo an argument of George Robertson, MP:

her attacker, the victim said, "Maybe they [the jury] would have believed me if he' $d$ stabbed me with the knife he used to threaten me." Id.

277. John Robertson, Verdict That Causes Headaches for Judges - But Relief for Those Freed, ScoTSMAN, May 27, 2003, http://news.scotsman.com/archive.cfm?id=592842003 (last visited Mar. 22, 2005).

278. Id.

279. Neighbors Tell of Ordinary Mum They Knew Couldn't Murder a Child, EDINBURGH EVENING NEwS, Mar. 8, 2003, http://news.scotsman.com/topics.cfm?tid=790\&id=285952003 (last visited Mar. 22, 2005).

280. Baby Murder 'Not Proven', BBC NEws, Mar. 7, 2003, http://news.bbc.co.uk/1/hi/ scotland/2830323.stm (last visited Mar. 22, 2005).

281. John Robertson, Anger as Minder is Cleared of Child's Murder, SCOTSMAN, Mar. 8 , 2003, http://news.scotsman.com/archive.cfm?id=281962003 (last visited Feb. 16, 2005).

282. Robertson, supra note 277.

283. Id.

284. Id.

285. Diane King, Where is Justice for Our Wee Boy?, EDINBURGH EvEnING NEWS, Mar. 8, 2003, http://news.scotsman.com/index.cfm?id=284952003 (last visited Feb. 16, 2005).

286. Id.

287. Id. The Grahams' dissatisfaction pushed them to take action in civil court, where they claimed McLeod was responsible for the death of their son by either a deliberate or negligent act. Susan Mansfield \& Ian Johnston, Woman Cleared of Killing Baby Pays Sum to Parents, SCOTSMAN, Feb. 5, 2005, at 8 . A settlement was subsequently reported, admitting no guilt on the part of McLeod and paid for by her insurance company. Id. Mrs. Graham is pursuing more than a monetary settlement, because she insists that "[i]t was never about the money." Susan Mansfield, After Alexander Died We Wanted to Gas Ourselves to Death in Car, ScotsmaN, Feb. 5, 2005, at 8 . She also wants "reform of the criminal justice system to prevent further suffering." Id. "[O]n top of Alexander dying," she said, "it was made so much worse for us by the legal system." Id. "A 'not proven' verdict is a terrible thing ... [and] should not exist. ... It just left completely open the issue of what had happened to Alexander." Id. Focusing on the jury, she stated: 
"There is a legacy of frustration left behind by victims and their families where all that remains is a mystery. People throughout Scotland feel that the not proven verdict leaves in its wake an air of constant frustration and aggravation that cannot do the system any good." ${ }^{288}$ The jury was so distressed by McLeod's case that, after they had returned the not proven verdict, the judge excused them from further jury service for a decade. ${ }^{289}$

American families faced the potential for this type of frustration in January of 2001, when a Scottish court delivered the verdicts for the accused bombers of Pan Am flight 103. ${ }^{290}$ A panel of three Scottish High Court judges located in the Netherlands began hearing the case against the two accused terrorists in the spring of 1999 , more than ten years after the plane fell to earth over Lockerbie, Scotland, killing 270 people, of which 189 were American. ${ }^{291}$ Despite worries and criticisms over the not proven verdict, Scots remained proud of their system, hoping that when American lawyers saw it at work, even in the unusual circumstances of the Lockerbie trial, they would have confidence that justice had been done. ${ }^{292}$

At the time of trial, public opinion was split over the possible verdicts even though "the Scottish system does mirror the American system in many ways." ${ }^{293}$ The Pan Am 103 case was the first time a Scottish Court sat abroad, and the first time serious criminal charges were tried by judges rather than a jury. ${ }^{294}$ One professor of Scottish law, admittedly not knowing how strong the case was, suggested that "[i]t is probably more difficult to convict under Scottish law than American or English because there are stricter rules of evidence." 295 Even so, another professor of Scottish criminal law stated, "My guess would be that the judges would not hide behind [the not proven] verdict.

We felt it was the easy way out for the jury. It allows them to avoid the fundamental question of guilt or innocence. They didn't have to make a decision, it was a non-decision. They should have had to make a decision and live with the consequences, as we've had to live with the consequences of their lack of decision.

Id.

288. Hansard, supra note 25 , at 231.

289. King, supra note 285.

290. Marjorie Miller \& Maggie Farley, We've Learned There Is No Formula for Grieving, L.A. TIMES, Feb. 1, 2001, at A1.

291. Marjorie Miller, Pan Am Bombing Case May Be Difficult, L.A. TIMES, Apr. 13, 1999, at A21. "More than 400 parents lost sons or daughters in the bombing; 46 parents lost an only child; 65 women were widowed; 11 men lost wives; more than 140 children lost a parent; seven children lost both parents." Miller \& Farley, supra note 290.

292. Alistair Bonnington, Scots Criminal Procedure and the Lockerbie Trial, 11 INT'L LEGAL PERSP. 11, 28-29 (1999).

293. David E. Rovella, Flight 103 Highlights Scots' Law, NAT’L L. J., Apr. 26, 1999, at A1. Even so, Rovella admits that "[a]t first glance, the jurisdictional complications of the trial of those accused in the 1988 bombing . . could give any lawyer a migraine." Id.

294. Miller, supra note 291.

295. Id. 
If they feel the case has not been ruled beyond a reasonable doubt, they would return a verdict of 'not guilty'.,"296

Her guess turned out to be correct, the result being one verdict each of guilty and not guilty. ${ }^{297}$ One of the family members equated the two verdicts of acquittal in his expected outcome: "I think most of us had resigned ourselves to either a not-guilty or not-proven verdict .... There was just not enough evidence to prove both of them were involved .... We accept that, and we're real happy with the guilty verdict."298 A woman whose husband died stated that she "shook with joy and sadness when she heard the verdict on the morning news." 299

\section{B. American Bastardization of That Bastard Verdict}

For Americans, the verdict of "not proven" was made famous that same year, prior to the case of Pan Am 103, when Senator Arlen Specter, a Pennsylvanian republican, chose it over a guilty vote during the impeachment trial of President William Jefferson Clinton. ${ }^{300}$ Relying on the "tradition in Scottish courts," he voted not proven rather than not guilty when the roll was called for the Senate's verdict. ${ }^{301}$

One reason for his vote of not proven was that the Senate prohibited live testimony from witnesses, and only allowed videotaped testimony from three of the fifteen witnesses on the list from the House. ${ }^{302}$ This limitation, he suggested, tied one hand behind the back of the House prosecutors. ${ }^{303}$ "This is not to say the president is not guilty, but to specifically say that the charges have not been proven," he explained. ${ }^{304}$ "My view is the Senate has done partial justice." 305

Specter's choice of intermediacy was based on "undue restrictions" imposed on House Managers in the presentation of their case, which resulted in the hearing of only part of the evidence. ${ }^{306} \mathrm{He}$ knew when he cast a vote for acquittal that there was a risk of backlash from both sides of the political spectrum. ${ }^{307}$ Still, he held to the view that:

296. Mark Libbon, Walsh Says He Likes Bush's Conservatism, SYRACUSE PosTSTANDARD, Nov. 28, 1999, at A10.

297. Miller \& Farley, supra note 290.

298. Id.

299. Id.

300. Rovella, supra note 293.

301. Specter Says House Failed to Prove Case, INTELLIGENCER J. (Lancaster, PA), Feb. 11 , 1999, at A1.

302. Id.

303. Id.

304. Id.

305. Id.

306. Specter Justifies His "Not-Proven" Verdict, PItTSBuRgh Post-GaZETTE, Feb. 11, 1999, at A12 [hereinafter Specter Justifies].

307. Lisa Fine, Specter Blasted for Vote in Trial, INTELLIGENCER J. (Lancaster, PA), Feb. 
House Managers could not meet the heavy burden of proof beyond a reasonable doubt .... [O]n this record, the proofs are not present .... Given the option [of not proven] in this trial, I suspect that many Senators would choose 'not proven' instead of 'not guilty' .... The President has dodged perjury by calculated evasion and poor interrogation. Obstruction of justice fails by gaps in the proofs. ${ }^{308}$

Regardless of Specter's suspicions, "there was a pause of hushed murmuring on the Senate floor" when he announced his unique vote. ${ }^{309}$

As early as 1985, questions of how the not proven verdict developed and how it might be used in America were being posed. ${ }^{310}$ It was seen as "useful in a system that allows conviction not by 12 unanimous jurors, as in most American states, but by a majority vote among 15 ."311 "The middle option," it was suggested, "helps to focus a jury's attention on the weaknesses in the evidence." 312 Even so, it was thought that the verdict "wouldn't and shouldn't take root in America." 313 This was because "[i]ts potential for tainting some defendants would outweigh whatever value it has in springing others. Our stark choice has a virtue; jurors are given no way to proclaim that they harbor suspicions about the defendant even though they can't convict him."

Curiosity about a third verdict did not abate, however, and the American Bar Association Journal reported in 1994 that a handful of criminal defense attorneys in Atlanta, Georgia, wanted not proven added to the verdict form. ${ }^{315}$ "It's totally legitimate and well within the law," one lawyer said. ${ }^{316}$ The Assistant United States Attorney thought otherwise: "What the defense lawyers should be seeking is not another verdict, but better, [clearer] instructions by the

18,1999 , at A1.

308. Specter Justifies, supra note 306.

309. Fine, supra note 307. The responses Specter received from the public, on the other hand, were "deafening," expressing surprise and confusion. Id. These included: "Why don't you move to Scotland?"; "Hey Specter!!! HELLOOOOOO. We don't live in Scotland, or hadn't you heard? ... If it weren't so sad, it would be funny. I'm disgusted."; "I think you look good in kilts. You have nothing to hide under them."; "What a spineless wonder you are .... You are a coward without a conscience." Id.

310. John P. MacKenzie, The Editorial Notebook; Between Guilt and Innocence, N.Y. Times, Aug. 16, 1985, at A28.

311. Id.

312. Id.

313. Id.

314. Id. Another writer submits: "The Scots have given us many valuable imports, but the 'not proven' verdict is one we are better off without." Edwin M. Yoder Jr., Ed Meese in the Twilight Zone, WASH. POST, Aug. 1, 1988, at A13. He described the not proven verdict as "the sort of legal limbo to which juries might condemn a highlands chicken thief who had eaten the evidence he stole but was known by his peers to be guilty as all get-out." Id.

315. Debra Cassens Moss \& Mark Curriden, Prove It, 80 A.B.A.J. 42 (1994).

316. Id. 
judge to the jury." 317 The obvious prediction was an increase in acquittals, based on the fact that "[j]urors are known to compromise whenever possible, and this gives them a way out."

A year later, during the trial of O.J. Simpson, the possibility of a third verdict was again raised in a case where "American jurors have freed a defendant whom they think culpable." 319 The discussion arose in part from a common refrain of jurors having just returned a not guilty verdict: the belief that "the defendant likely did something wrong, but that the prosecution didn't prove its case beyond a reasonable doubt." 320 "The usual result is disappointment for the prosecution and the victims or their survivors - and a feeling of a job half-done by jurors who know that while technically not guilty, the defendant was surely not innocent." 321

To avoid this outcome, many jurors expressed that they had "an option other than not guilty, one which more accurately expressed their feeling that the defendants were culpable of the crimes charged, but the prosecution had not cleared the legal hurdle needed to convict."322 "Returning a verdict of not proven in high-profile trials such as the O.J. Simpson ... [case] might also alleviate some of the outrage, dissonance and civil angst that [attend] the troubling outcomes of such cases." ${ }^{23}$ Nevertheless, Supreme Court Justice Antonin Scalia is wary of offering a third verdict: "I wouldn't favor it. . . I I sort of like the [current system's] clean-cut up or down." "324 Justice Scalia sees the not proven verdict as "a backhanded way to destroy a person's reputation without saying that he's guilty." 325

That same year in California, state senator Quentin Kopp intended to "revive legislation that would allow juries a third option between 'guilty' and 'not guilty': a middle ground called 'not proven'." ${ }^{26}$ His renewed interest came after the acquittal of O.J. Simpson, although he introduced the same legislation after the beating of Rodney King. ${ }^{327}$ In defense of the measure's introduction, Kopp's chief of staff said that the not proven option is allowed

317. Id. This is an ironic suggestion considering the repeated warnings against such instruction over the not proven verdict in Scottish courts. See discussion supra Part II.B.

318. Id.

319. Mark I. Pinsky, When Juries Need a $3^{\text {rd }}$ Choice: Not Proven, ORLANDo SENTINEL, Aug. 20, 1995, at G1.

320. Id.

321. Id. Pinsky says that after writing about several large criminal cases, he is aware that "one of the most common mistakes reporters make in covering such proceedings - apart from thinking they can argue cases better than lawyers - is equating acquittal with exoneration." Id.

322. Id.

323. Id.

324. Id.

325. Id.

326. Bill Ainsworth, Anti-Crime Politicians Quick to Exploit Verdict, RECORDER, Oct. 4, 1995, at 14.

327. Id. He said that the not proven verdict "would have mollified a good many indignant people" had it been available in the Simpson case. Id. 
and works well in Scotland. ${ }^{328}$

However, the American Civil Liberties Union opposed the legislation in order to avoid confusing jurors and judges with a new instruction after twohundred years of guilty or not guilty. ${ }^{329}$ They also stated that the change would "stand the presumption of innocence on its head, because it fosters the perception that everyone charged with a crime and brought to trial is a little bit guilty." 330 Essentially, it was argued that "once released, a person found "not proven' would carry a state-sanctioned stigma."331 Kopp's proposal was defeated three votes to two in April of 1996. ${ }^{332}$ But in February of 2003, another bill providing for a jury verdict of not proven was introduced by Senate President Pro Tem John Burton. ${ }^{333}$ On May 6, 2003, in a three to one vote, the bill failed passage from the Senate Public Safety Committee, "but was granted a chance to be reconsidered at a later date." 334

Late in 2002, the Third Circuit Court of Appeals provided some insight into how the not proven verdict clashes with American principles of collateral estoppel and jury unanimity, when it denied a motion to dismiss based on the use of the not proven verdict. ${ }^{335}$ In Merlino, the court rejected a mobster's double jeopardy argument and "ruled that reputed Philadelphia Mafia boss Joseph 'Skinny Joey' Merlino [could] be tried again . . . on a murder charge that a ... jury last year found 'not proven'.,"336

The Circuit Judge decided that because the jury was given faulty instructions during deliberations concerning the use of not proven, it may have chosen the verdict even though it had never reached a unanimous decision on

328. Senator Calls for Allowing Jury Verdicts of Not Proven, METRO. NEWS ENTER. (Los Angeles), Jan. 22, 1996, at 11.

329. Id.

330. Pamela Martineau, Senate Panel Approves Measure Aimed at Limiting Reach of Three-Strikes Law to Serious Felonies, METRO. NEws ENTER. (Los Angeles), Apr. 24, 1996, at 11.

331. Kopp Trying to Tinker With A Proven Success, Metro. News ENTER. (Los Angeles), Feb. 5, 1996, at 9.

332. Id.

333. End of the Month, Metro. News EnTER. (Los Angeles), Feb. 28, 2003, at 7.

334. End of the Month, METRo. NEws ENTER. (Los Angeles), May 30, 2003, at 7.

335. United States v. Merlino, 310 F.3d 137, 144 (3rd Cir. 2002). "This case is the tale of two indictments, one in Pennsylvania and one in New Jersey. A multi-defendant, multi-count trial took place in the United States District Court for the Eastern District of Pennsylvania." Id. at 139.

336. Shannon P. Duffy, The Skinny on Merlino's Philadelphia Conviction, LEGAL INTELLIGENCER, Nov. 11,2002, at 1 . Merlino was acquitted of three counts of murder and two counts of attempted murder after a four-month trial, covering thirty-six indictments, where fifty witnesses were called to the stand and almost a thousand pieces of evidence were presented. 7 Reputed Mafia Figures Are Acquitted of Murder, N.Y. TIMES, July 21, 2001, at A8. The jury still found Merlino guilty on eleven acts of racketeering. Steven P. Bann, United States v. Merlino, N. J. L. J., Nov. 18, 2002. The debate concerning double jeopardy arose when the government soon after indicted Merlino a second time on different racketeering provisions, but included the charge of conspiring to commit the murder brought in the first trial. Id. 
the charge that Merlino participated in the shooting of a Mafia captain. ${ }^{337}$ Merlino's attorney argued that "collateral estoppel principles required dismissal" of the second indictment because the jury "had entered a valid and final judgment, effectively acquitting" Merlino of the slaying. ${ }^{338}$ But the burden was on Merlino, who failed because he could not prove the jury unanimously acquitted him. ${ }^{339}$ Thus, the issue of his participation in the murder was not precluded. ${ }^{340}$

But the spirited dissent suggested that the majority should have "tossed out the New Jersey indictment on double jeopardy grounds." "I I submit," Judge Nygaard said, "that looking behind jury verdicts to reconstruct the jury's thinking, or attempting to determine how it may have reached consensus, is pure speculation and contravenes our fundamental constitutional heritage of treating jury verdicts as unimpeachable." ${ }^{342}$ Instead, his contention was that not proven verdicts "should be treated as acquittals for collateral estoppel purposes." 343 Otherwise, the defendant could be "forced to prove his innocence of that charge repeatedly," which defeats "the purpose of the Double Jeopardy Clause and collateral estoppel[,] to protect defendants from having to face serial trials for the same offense." 344

Setting aside the issues of collateral estoppel and jury unanimity, Merlino at least establishes an international context for the assertion that giving instructions on the use of the not proven verdict can be "highly dangerous" and

337. Duffy, supra note 336 . The judge said that the faulty instruction:

makes the jury's vote ambiguous because we cannot tell from the face of the verdict sheet whether the vote was unanimously "Not Proven" or whether the jury unanimously decided that they were unable to reach a unanimous decision as Id. to "Proven" or "Not Proven," . . . whether they were "hung" on that issue.

338. Id.

339. Bann, supra note 336.

340. Id. The court held:

[D] espite the notations on the special verdict sheet, Merlino cannot prove that the jury unanimously, or even by a majority, acquitted him of participation in Sodano's murder, and thus he cannot foreclose litigation of that issue. On the special verdict sheet, the Pennsylvania jury checked "Not Proven" boxes corresponding to the Sodano murder. Because, however, of the supplemental instructions given by the District Court, those check marks are ambiguous. They do not demonstrate that the jury unanimously found that the Sodano murder was "Not Proven."

Merlino, 310 F.3d at 142.

341. Duffy, supra note 336.

342. Merlino, 310 F.3d at 144 (Nygaard, J. dissenting). "[W]e do not know how the jury voted after the judge issued the second supplemental instruction, and we should not pretend that we do. We only know that it decided that this predicate act [murder] was not proven." Id.

343. Id. "Here, however, the jury was not 'hung.' It returned a verdict. We have a final judgment. The jury's decision on the murder-based predicate acts was the functional equivalent of a verdict on the stand-alone murder charge." Id. at 144-45.

344. Id. 
likely to result in an appeal. ${ }^{345}$ When taken in conjunction with the larger arguments against the not proven verdict voiced by Americans when the topic has briefly arisen, one has to wonder if implementation of a three-verdict system would improve of the delivery of justice in any particular state, or in the United States at large.

\section{FLOWER OF SCOTLAND}

Like Scotland's distinctive national flower, the thistle, the not proven verdict is prickly and has definitely stuck. Even so, some wonder if the institution of the jury, let alone the not proven verdict, should be kept at all. ${ }^{346}$ "[T] he acid test must always be, does the system deliver justice?"347 In terms of the not proven verdict, as with juries, the answer is not always clear-even after more than three-hundred years and two formal governmental reviews. ${ }^{348}$ Indeed the question remains: "[I]f all that was left [of the Scottish legal tradition] were the not proven verdict and the somewhat elusive concept of corroboration to distinguish Scots law ... would it be worth keeping?"349

Late in 2004, a Member of Scottish Parliament (MSP) reinvigorated the debate over the controversial verdict. ${ }^{350}$ Michael McMahon of the Labour party proposed a bill that would do away with the option of not proven. ${ }^{351}$ This was the first move to have the verdict abolished within the Scottish Parliament ${ }^{352}$ since it devolved in $1998 .{ }^{353}$ For the bill to formally go before Parliament, it must have a minimum of eighteen signatures from other MSPs. ${ }^{354}$ McMahon apparently has wide support among those in his party, and the First Minister of the Scottish Parliament ${ }^{355}$ "is not averse to the idea of debating the issue." ${ }^{\text {"356 }}$ In an echo of its response prior to Firm and Fair, the Scottish Executive insisted, "This is not in our immediate priorities," but added, "We will be interested to

345. See supra notes 100-103, and accompanying text (discussing McDonald v. HM Advocate).

346. See generally Bonnington, supra note 140.

347. Id.

348. Id.

349. Lord Dervaird, Afterword: Prospects for the Future, in THE SCOTTISH LEGAL TRADITION 91 (new enlarged ed., Scott C. Styles, ed., 1991). Writing in 1991, Lord Dervaird states that "there have been voices prophesying or urging the end of an auld sang. The times, it is said, are against the survival of Scots law as an independent system." Id.

350. Stuart Nicolson, MSP bids to scrap Scotland's historic not-proven verdict, DAILY MAIL (London), Nov. 22, 2004, at ED SC1 O4, 2.

351. Id.

352. Id.

353. See supra note 2 and accompanying text.

354. Nicolson, supra note 350.

355. The First Minister of the Scottish Parliament is equivalent to the Prime Minister in the British Parliament.

356. Kirsty Scott, Move to Scrap Scots Option of Not Proven Verdict: Private Member's Bill Said to Have Wide Backing, GUARDIAN (London, Final Edition), Dec. 2, 2004, at Guardian Home Pages 10. 
see what support the bill attracts." ${ }^{357}$ McMahon plans to draft the bill early in 2005 "with a view to presenting a final version for Parliament to debate before Christmas 2005."358

McMahon's foundational argument is that the "present system leaves the person who was charged of the crime without exoneration, and it leaves the victim or their family feeling that no justice has been done. That is an unsatisfactory situation and must be changed. ${ }^{\text {,39 }} \mathrm{He}$ has also argued that "juries should be asked to come to a definitive conclusion."360 "It has always been in my mind that this is something the Scottish Parliament could change." ${ }^{361}$ Once again, positions are being taken on both sides, either supporting the difference in emphasis that not proven provides (between it and not guilty), or calling for a two-verdict system relieving jurors of the ability to "pronounce on shades of guilt.",362

Joe Duffy, father of murdered Amanda Duffy, has again taken up the cause, and supports McMahon's efforts toward definitive conclusions from juries: "That is what anybody in court ... [and] the family of a victim deserves: a clear cut verdict. Not 'maybe', which is what not proven is. It leaves a question mark." ${ }^{363}$ He hopes that McMahon's bill will bring Scotland "into line with the rest of the world," 364 and "into the 20 th century, never mind the 21st."

McMahon's position has taken on an element of nationalism, because he believes that the verdict "does not serve Scotland well.",366 He feels that the "Scottish judicial system is something of which the country is rightly proud, yet it contains an anomaly [the not proven verdict] which too often brings the system into disrepute. ${ }^{, 67}$ He suggests that the third verdict is a legitimate concern for MSPs, because it "allows Scots law to be ridiculed by not providing adequate justice for either the victim or often for the accused ....,368 But the sentiment of nationalism goes both ways, as evidenced by proponents' arguments, such as, "[w]e have an ability in our country, which no other

357. Russell Fallis, MSP Bid to Kill Off the Third Verdict, SUNDAY EXPRESS (Highlands Edition), Nov. 21, 2004, at NEWS 2.

358. Lindsay McGarvie, In the Dock: MSP Bids to Axe 'Not Proven' End to Court Cases, SuNDAY MAIL (First Edition), Nov. 21, 2004, at NEWS 13.

359. Findlay Set to Pen Defence of Not Proven Verdict; Victims' Families Angered over Book on 'Third Verdict', SUNDAY HERALD, Jan. 16, 2005, at NEWS 9 [hereinafter Findlay Set to Pen Defence of Not Proven Verdict].

360. Nicolson, supra note 350.

361. McGarvie, supra note 358. McMahon first became aware of the not proven verdict through the murder case of Amanda Duffy, which took place in the area he now represents. Id.

362. Id. (quoting Gordon Jackson, QC).

363. Scott, supra note 356.

364. MSP Moves to Scrap Not Proven Verdict, Herald (Glasgow), Nov. 22, 2004, at 6.

365. Findlay Set to Pen Defence of Not Proven Verdict, supra note 359.

366. Scott, supra note 356.

367. MSP Moves to Scrap Not Proven Verdict, supra note 364.

368. McGarvie, supra note 358. 
country has, to give an indication that a jury are simply dissatisfied with the prosecution [sic] case." 369

Some argue that the option to rid Scots law of the not proven verdict altogether would be purposeless. ${ }^{370}$ The justice spokesman for the Scottish National Party, Kenny MacAskill, feels it would be wrong to rush into abolishing the current system, and stated that he is "loath to abolish it without a full consideration of what it might mean."371 "We should think long and hard before we legislate..." he said. ${ }^{372}$ It might mean quite a lot. For instance, one commentator has suggested that the eight-to-seven majority required for a verdict would be an untenable ratio if Scotland switched to a two-verdict system. ${ }^{373}$ Instead of abolition, MacAskill suggested an alternative: "[I]f there has to be a change, it should be back to what was historically the case in Scotland, which was an option of 'proven' and 'not proven', rather than 'guilty' and 'not guilty'.,"374

The question of whether the system in place satisfactorily delivers justice transcends mere cultural history and tradition. Indeed, any benefit or detriment to these must be penultimate to the mandatory requirement that justice is provided through the Scottish legal system. This does not mean, however, that simply because the methodology - or in this case, the terminology-used is unique or different, that it should be cast aside as less effective. This is especially true with the not proven verdict, where altering what makes Scots law unique would have a rippling effect requiring change at a more systemic level, such as adjusting the number of jurors or the level of agreement among jurors to convict (i.e., simple majority as opposed to unanimous decision). ${ }^{375}$

369. Scott, supra note 356 (quoting Derek Ogg, QC). The third verdict is viewed by some Scots as "certainly a peculiarly Scotch one, and, for this alone, some of us are attached to it." Massie, supra note 24.

There is something characteristically hair-splitting about it: "We'll no' say you did it, but then we'll no' affirm ye didna either." This is not only a very Scots response, expressed otherwise as "awa' ye gae and dinna dae it again": it also expresses an admirable scepticism, so admirable indeed that it may well be the most honest verdict a jury can truly give.

Id.

370. Massie, supra note 24. The author concludes with an eye towards nationalism: "It's probable that the current rage for innovation, and Labour's zeal to get rid of something merely because it is long-established, will result in the end of the 'bastard verdict.' If so, something else distinctively Scottish will have disappeared, and this to no great purpose . . . ." Id.

371. Nicolson, supra note 350.

372. Id.

373. Scott, supra note 356 (quoting Derek Ogg, QC). "If you change it, you need to start changing the numbers on the jury and some people might be concerned about that." $I d$. Some people are already expressing their concern: "[I]f Mr. McMahon gets his way, Scotland will follow the English route of hung juries and retrials where the same evidence will be heard in the same glare of publicity and at huge public cost." Sam Clarke, Three-Verdict System Makes Perfect Sense, Evening Times (Glasgow), Nov. 25, 2004, at 10.

374. Nicolson, supra note 350 . MacAskill suggests that this approach gets "back to the logic of what a sheriff or jury is being asked to consider ...." Id.

375. See supra notes 371-73 and accompanying text. 
Many proponents of abolishing the third verdict might welcome an overhaul of the system, and call for the additional steps required to change areas related to the not proven verdict. The costs of this approach would be significant, and there is no guarantee, once the dust has settled, that the delivery of justice would be any more satisfactory.

Considering whether substituting a two-verdict system of guilty/not guilty, like that used in the United States, would prevent dissatisfaction makes this more evident. If, for example, the Aulds or the Grahams had their cases heard in the American legal system, resulting in the same outcome (acquittal for the accused), their level of dissatisfaction would persist because the underlying cause of that dissatisfaction-what happened to their children-would remain unanswered in their minds. The same holds true for the unsatisfactory stigma apparently placed upon those acquitted by a Scottish court under a not proven verdict. ${ }^{376} \mathrm{~A}$ similar stigma is arguably placed upon any individual subjected to the severe scrutiny of the American legal process, and then acquitted. ${ }^{377}$ O.J. Simpson has become, of course, the exemplar. ${ }^{378}$

Arguing for a two-verdict system of proven/not proven instead of guilty/not guilty is essentially drawing a distinction without a difference. Even where the terminology is exchanged, the same issues of party dissatisfaction arise. Furthermore, a systemic change remains necessary in Scots law to accommodate two verdicts. However, retention of the language "not proven" would provide a secondary benefit for those seeking to preserve Scottish culture and tradition. If such a compromise were made, it could strike a balance between those wanting legal reform and those wanting to maintain Scotland's individuality. Or, as is the ever-vexing problem with the not proven verdict, such a compromise could be unsatisfactory for all.

To some extent, party dissatisfaction is inherent in a system of justice, regardless of whether it utilizes two or three verdicts. Moreover, some dissatisfaction is vital to the continued development of a socially acceptable system of justice. In this light, the passionate efforts by families such as the Aulds and the Grahams serve the crucial function of posing the pivotal question in this debate: Does our system deliver justice? ${ }^{379}$ The current outcome will likely seem harsh towards the Aulds and the Grahams. However, without more, the costs of systemic change to Scottish criminal law do not justify the perceived benefits of ridding it of the not proven verdict, or retaining "not proven" within a two-verdict system.

Ultimately, "whether there is a future for Scots law," and more specifically the not proven verdict, "will depend mainly on the respect and affection it engenders in the people of Scotland."380 As Lord Cooper phrases it,

376. See supra notes 53, 90, 94, 172, 174, 191, 213, 224, 240, 273 and accompanying text.

377. See supra text accompanying note 331 .

378. See supra text accompanying notes 319-21.

379. See supra text accompanying note 347.

380. Dervaird, supra note 349 . Like Duff's view of juries, Lord Dervaird considers the 
"The truth is that law is the reflection of the spirit of a people, and so long as the Scots are conscious that they are a people, they must preserve their law."381 Thus, the "Scottish people have good cause to place supreme value upon their system of jurisprudence," and should "support every effort to preserve its unique individuality." 382

Lord Cooper goes further to consider "Scots Law from a wider standpoint than merely local or domestic," seeing his country's legal tradition as "a thing to be prized both in Scotland and beyond its Borders." ${ }^{833}$ His vision is much more grandiose: "Scots law as it stands gives us a picture of what will some day be the law of the civilised nations, -namely a combination between the AngloSaxon system and the Continental system." "384 As for the present, "[i]n respect of the intermediate position which it now occupies between the two great schools of legal thought, Scots Law is at the moment unique.,"385

Scottish legal system as "a symbol, ... the pre-eminent symbol, of the existence of Scotland as a separate nation." Id. See supra note 156.

381. Cooper, supra note 7 , at 88 .

382. Id. at 89 . There is tension here, however, because Lord Cooper also thinks the law should be perfected "in its future service of the common purposes of Scottish society," which could arguably include abolition of the not proven verdict. Id. Id.

383. Id. at 87. In his view "the public of Scotland should be more conscious of [this] fact."

384. Id. (quoting legal critic Professor Levy Ullmann of Paris). This vision recently came under contention when the European Court of Human Rights agreed to review the not proven verdict to decide if it breaches "natural justice." Mark Macaskill, 'Not Proven' Verdict Faces European Test, SundAY TMmes (London), Jan. 16, 2005, at Scotland News 18. The family of a man stabbed to death in Glasgow in 2000 lodged an appeal with the court after review of the case was twice denied. $I d$. The family argues that the not proven verdict violates articles six and fourteen of the European Convention on Human Rights, which guarantee citizens the right to a fair trial, and the right not to be discriminated against. Id. In this instance, the family is arguing that the not proven verdict removes the presumption of innocence, and also allows the accused two chances of being acquitted while only one of being convicted, both of which result in an unfair trial. Id. Therefore, the family claims that "Scots are discriminated against because they live in the only country in the world that uses the not proven verdict." Id.

385. Cooper, supra note 7 , at 87. 
